\title{
Granito Encantada: registro de uma intrusão peraluminosa na Província Rondoniana - San Ignácio, no SW do Cráton Amazônico - MT
}

\author{
The Encantada Granite: registration of a peraluminous intrusion in the Rondonian \\ Province - San Ignacio, in SW Amazonic Craton, Mato Grosso, Brazil
}

Brena Verginassi do Nascimento ${ }^{1}$, Carlos Humberto da Silva², Ana Cláudia Dantas da Costa ${ }^{2}$

${ }^{1}$ Programa de Pós-graduação em Geociências, Instituto de Ciências Exatas e da Terra, Universidade Federal de Mato Grosso - UFMT, Avenida Fernando Corrêa s/n, Bairro Coxipó, CEP 78060-900, Cuiabá, MT, BR (brenaveg@gmail.com) 2Departamento de Geologia Geral, Instituto de Ciências Exatas e da Terra, Universidade Federal de Mato Grosso - UFMT, Cuiabá, MT, BR (chsilva@ufmt.br; acdcosta@ufmt.br)

Recebido em 26 de fevereiro de 2014; aceito em 04 de março de 2015

\begin{abstract}
Resumo
O Granito Encantada ocorre no extremo sudoeste do estado de Mato Grosso, SW do Cráton Amazônico, nas proximidades da fronteira Brasil - Bolívia. Corresponde a um corpo orientado segundo direção NNW, que intrudiu rochas metassedimentares e metavulcânicas. Consiste de leucogranitos de composição monzo a sienogranitica, marcado por uma xistosidade proeminente. Apresenta textura equigranular a inequigranular porfirítica, sendo composto por: quartzo, K-feldspato, plagioclásio, muscovita e biotita com granada, zircão, allanita, e minerais opacos. Clorita e epidoto são os minerais secundários mais comuns. $\mathrm{O}$ estudo geoquímico permite classificar o magmatismo como de caráter ácido, subalcalino, do tipo cálcio-alcalino de alto potássio a shoshonítico. São rochas com índice de saturação de alumina superior a 1, com coríndon normativo, sendo por isso classificado como um granito peraluminoso. Como reflexo do excesso de alumínio, apresenta diversas fases aluminosas, destacando-se muscovita e biotita, além de granada. Apresentam padrão típico de rochas cálcio alcalinas ricas em potássio com enriquecimento de ETR leves sobre pesados. Os dados coletados permitem considerar que as rochas do Granito Encantada foram geradas a partir da fusão parcial de rochas crustais de composição pelítica.
\end{abstract}

Palavras-chave: Granito Peraluminosos, Cráton Amazônico, Província Rondoniana - San Ignacio.

\begin{abstract}
The Encantada Granite occurs on the extreme southwest of the state of Mato Grosso, SW of the Amazonian Craton, near the border of Brasil/Bolívia. It corresponds to an body oriented to NNW direction that intruded metasedimentary and metavolcanic rocks. It consists of leucogranites with monzo- to sienogranitic composition, marked by prominent schistosity. It is characterized by equigranular to porphyritic inequigranular texture, and composed of quartz, K-feldspar, plagioclase, muscovite and biotite with garnet, zircon, allanite and opaque minerals. Chlorite and epidote are the most common secondary minerals. The geochemical study allows the classification of the magmatism as having acid character, sub-alkaline, high-potassium-calc-alkaline to shoshonitic type. These rocks have alumina index saturation higher than 1, with normative corundum, and thus classified as peraluminous granite. Due to the reflection of the excess of aluminium, they have various aluminous phases, mainly muscovite, biotite and garnet; presents typical pattern of calc-alkaline rocks rich in potassium with enrichment of light ETRs over the heavy ones. The collected data allows to consider that the Encantada Granite rocks were generated from the partial melting of crustal rocks of pelitic composition.
\end{abstract}

Keywords: Peraluminous granite, Amazonic Craton, Rondonian Province - San Ignacio. 


\section{INTRODUÇÃO}

A parte sudoeste do Cráton Amazônico é marcada por um sistema orogênico gerado por sucessivas acresções de arcos, com fechamento de bacias oceânicas e colisões de microcontinentes (Ruiz, 2005; Bettencourt et al., 2010). Um dos principais eventos registrados nesta porção do Cráton é o da colisão entre o protocráton Amazônico com o microcontinente Paraguá. Um dos registros dessa colisão ocorre na região da Serra de Santa Bárbara, no sudoeste do estado do Mato Grosso, Brasil. Trata-se do Terreno Rio Alegre, que compreende rochas vulcânicas máficas, ultramáficas, sedimentares químicas, além de intrusivas ultramáficas, máficas e félsicas. Estas rochas acham-se dispostas em uma estreita faixa de $20 \mathrm{~km}$ de largura, com orientação N30W (Figura 1).

Segundo Bettencourt et al. (2010), o Terreno Rio Alegre apresenta uma complexa evolução que se inicia com o estágio de abertura onde foram depositadas as rochas sedimentares e vulcânicas máficas e ultramáficas do Complexo Metavulcano-Sedimentar Rio Alegre. Em etapa posterior, as rochas da litosfera oceânica foram consumidas em zonas de subducção, gerando um arco magmático intraoceânico, formado por rochas plutônicas cálcio-alcalinas da Suíte Intrusiva Santa Rita. Posteriormente, este conjunto de rochas foi deformado e metamorfizado em um processo de soft collision. Um componente adicional da evolução geológica deste terreno foi reconhecido por Silva et al. (2012), o qual descreveu rochas graníticas de natureza peraluminosa agrupadas sobre a alcunha de Granito Encantada. Estas rochas são intrusivas no Complexo Metavulcano-Sedimentar Rio Alegre. O objetivo deste trabalho é a caracterização geológica, enfatizando aspectos petrográficos e geoquímicos das rochas do Granito Encantada.

\section{CONTEXTO GEOLÓGICO REGIONAL}

A área estudada situa-se no SW Cráton Amazônico, que foi compartimentado por Tassinari e Macambira (1999) em seis províncias, sendo elas: Amazônia Central (2,5 Ga), MaroniItacaiunas $(2,2-1,95 \mathrm{Ga})$, Ventuari-Tapajós $(1,95-1,8 \mathrm{Ga})$, Rio Negro-Juruena $(1,8-1,55 \mathrm{Ga})$, Rondoniana-San Ignácio (1,55 - 1,3 Ga) e Sunsás (1,3 - 1,0 Ga). O Granito Encantada ocorre na porção sudoeste do Cráton Amazônico, na região SW do estado de Mato Grosso, denominado por Cordani e Teixeira (2007) e Bettencourt et al. (2010) de Província Rondoniana-San Ignácio (Figura 1). Segundo a concepção destes autores, essa província é um orógeno colisional marcado pela amalgamação de arcos magmáticos intraoceânicos e prismas acrecionários durante o Mesoproterozoico.

A Província Rondoniana-San Ignácio é composta por: (1) Terreno Jauru (1,78 - 1,42 Ga), que inclui um embasamento Paleoproterozoico (1,78-1,72 Ga) e os orógenos acrescionários Cachoeirinha (1,56 - 1,52 Ga) e Santa Helena $(1,48-1,42 \mathrm{Ga})$, desenvolvidos em forma de arco magmático do tipo andino; (2) Terreno Paraguá $(1,74-1,32 \mathrm{Ga})$ marcado por unidades pré-San Ignácio $(>1,64 \mathrm{Ga})$ e pelo Complexo Granitoide Pensamiento (1,37 - 1,34 Ga), desenvolvidos em forma de um arco magmático de tipo andino; (3) Cinturão Alto Guaporé $(<1,42-1,34 \mathrm{Ga})$ com unidades desenvolvidas em uma bacia de margem passiva e de um arco intraoceânico; e (4) Terreno Rio Alegre (1,51 - 1,38 Ga), onde situa-se o Granito Encantada, composto por unidades geradas em dorsais meso-oceânicas e em arcos magmáticos.

Segundo Bettencourt et al. (2010), as rochas do Terreno Rio Alegre foram acrescidas ao paleo-Cráton Amazônico em um evento colisional datado em 1,34 a 1,32 Ga durante o qual foram geradas deformações, metamorfismo de alto grau e fusão parcial. A sua cratonização teria ocorrido entre 1,30 e $1,25 \mathrm{Ga}$ e foi seguida por reativação tectônica, deformação, sobreposição termal e magmatismo relacionados ao evento orogênico Sunsás.

O Terreno Rio Alegre, segundo Matos et al. (2004) e Ruiz (2005), é marcado por uma associação de rochas vulcânicas básicas a intermediárias e rochas sedimentares químicas e clásticas, cortadas por rochas intrusivas ultrabásicas, básicas, intermediárias e ácidas (Figura 1). A estratigrafia deste terreno foi objeto de estudo dos trabalhos de Matos (1995) e Matos et al. (2004), com dados complementares publicados por Geraldes (2000) e Ruiz (2005).

A sequência estratigráfica do Terreno Rio Alegre é marcada pelo Complexo Metavulcano-Sedimentar Rio Alegre, constituído da base para o topo das formações Minouro, Santa Isabel e São Fabiano. Segundo Matos et al. (2004), a Formação Minouro é composta por metabasalto associado a metassedimentos químicos (cherts e formações ferríferas bandadas). As rochas apresentam poucas modificações estruturais pós-cristalização com minerais metamórficos substituindo os magmáticos, sem obliteração da estrutura pretérita nas quais ainda é possível distinguir texturas porfiríticas e relictos de textura subofítica.

Conforme descrito por Matos et al. (2004), a Formação Santa Isabel apresenta vulcanismo de fácies lavas coerentes e rochas piroclásticas. A composição geral sendo metadacitos e riolitos, com fragmentos lapilis imersos em matriz microcristalina, parcialmente substituídos por carbonatos. $\mathrm{Na}$ Formação São Fabiano, Matos et al. (2004) descrevem rochas metassedimentares químicas como metacherts e formações ferríferas bandadas, que apresentam cores variadas, granulação fina e estrutura xistosa e/ou bandada, além de metassedimentos clásticos como sericita-quartzo xisto, com biotita e eventualmente granada.

Dados apresentados por Matos et al. (2004) mostram que a assinatura química das rochas da Formação Santa Isabel sugere sua geração em arcos de ilhas, o que é corroborado pelos dados U-Pb em zircão em duas rochas metadacíticas 

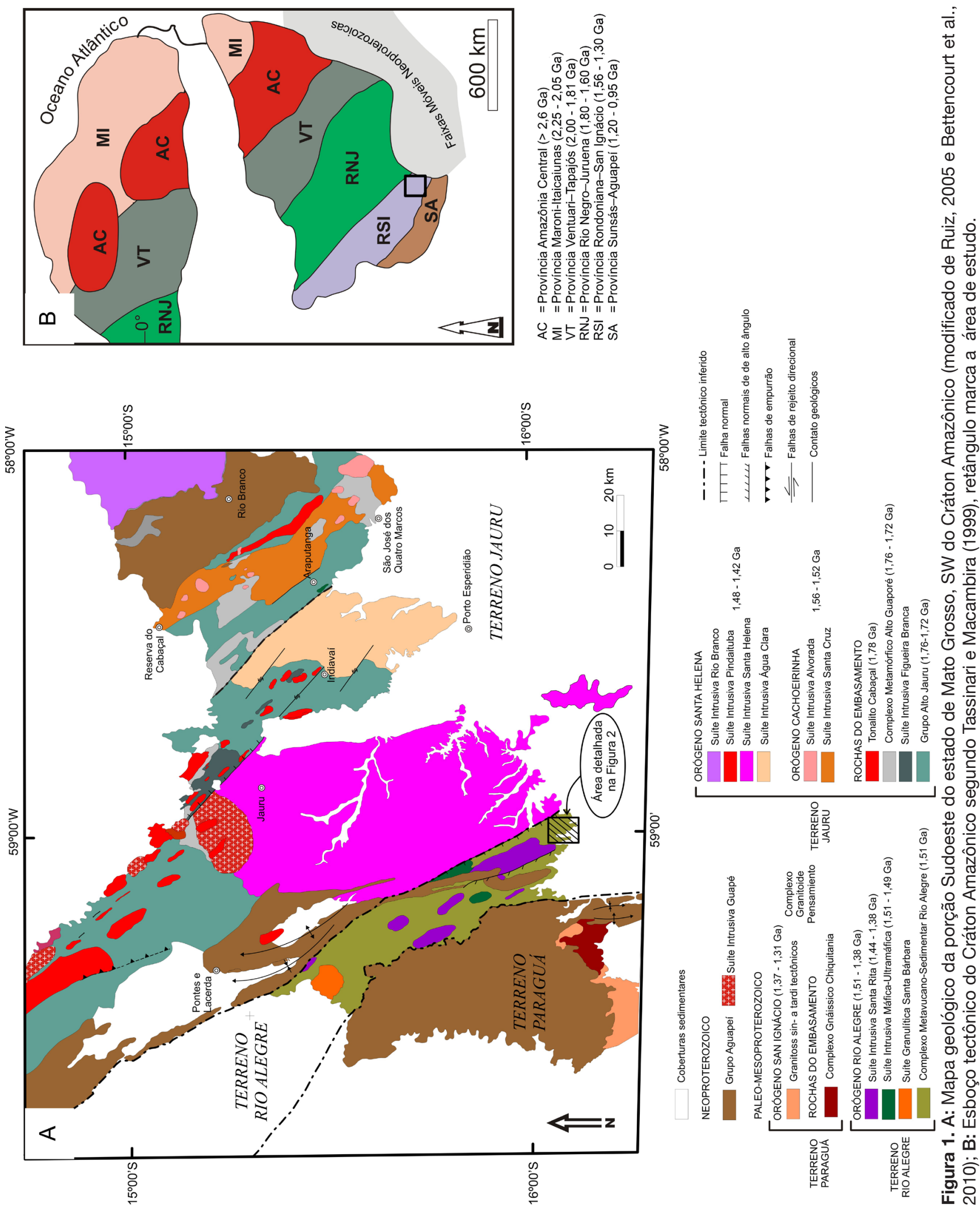
(idades de $1509 \pm 10 \mathrm{Ma}$ e $1503 \pm 14 \mathrm{Ma}$ ) e $\mathrm{T}_{\mathrm{DM}}$ de 1,54 Ga e $1,48 \mathrm{Ga}$ e valores de $\varepsilon_{\mathrm{Nd}(\mathrm{t})}$ respectivamente de $+4,3 \mathrm{e}$ $+4,8$ indicando derivação mantélica.

Ruiz (2005) descreve rochas básicas e ultrabásicas intrusivas nas rochas do Complexo Metavulcano-Sedimentar Rio Alegre. Estas rochas são peridotitos, harzburgitos, leucogabros, gabros e serpentinitos, meso a melanocráticos, de granulação grossa a muito grossa e com texturas cumuláticas denunciando diferenciação in situ.

Para Ruiz (2005), a Suíte Intrusiva Santa Rita é constituída por uma associação que varia de monzogabros a monzogranitos, de metaluminosos a peraluminosos. Propõe que as rochas menos diferenciadas foram geradas em um ambiente pré-colisional, embora quando plotadas nos diagramas de ambientes tectônicos de Pearce (1996), ocupam os campos de arco vulcânico a intraplaca. Assim pode-se interpretar que a evolução dessa suíte se inicia com um arco vulcânico representado pelas rochas menos evoluídas (1412 Ma) e passam a ambientes pós-colisionais (1380 Ma).

\section{CARACTERIZAÇÃO GEOLÓGICA DO TERRENO RIO ALEGRE NA ÁREA ESTUDADA}

As rochas do Terreno Rio Alegre na região estudada afloram em poucos locais, principalmente nos leitos dos rios perenes e em algumas encostas de morro. O Granito Encantada ocorre intrusivo nas rochas do Complexo Metavulcano-Sedimentar Rio Alegre, sendo que no entorno do batólito é representado por rochas metabásicas associados a metassedimentos químicos (Figura 2).

Dentre as rochas básicas destacam-se os anfibolitos e metagabros. Os anfibolitos são rochas verdes a verdes escuras, com granulação fina a média, composto por clorita, anfibólio e plagioclásio, que estão orientados definindo uma xistosidade. É frequente a ocorrência de sulfetos, principalmente pirita e calcopirita e de agregados de epidoto. Os metagabros são marcados por plagioclásio e quartzo, com anfibólio e biotita em menor proporção. Apresentam granulação média a grossa e pouca deformação, o que permite distingui-los dos anfibolitos. Associadas às rochas vulcânicas básicas ocorrem rochas metavulcânicas intermediárias tais como metadacitos e metandesitos. Dentre as rochas metassedimentares químicas destaca-se o metachert que é branco e apresenta granulação fina a muito fina, sendo composto por quartzo, hematita e mica branca em menor proporção. A estrutura proeminente é um bandamento composicional marcado pela variação de cores, que denotam a variação no conteúdo de óxido de ferro e quartzo. Nestas rochas é comum a presença de sulfetos. A formação ferrífera bandada metamórfica exibe um bandamento composicional com cores variando de cinza escuro a preto e granulação fina a muito fina, sendo basicamente composta por óxido de ferro e quartzo.
No entorno do Granito Encantada também aflora o Granito Ellus, parte da Suíte Intrusiva Santa Rita. O Granito Ellus foi estudado por Campos (2008), que caracterizou duas fácies petrográficas, cinza e rosa, sendo representado por rochas de composição granodiorítica a monzogranítica (fácies granodiorito a monzogranito) e sienogranítica (fácies sienogranito). Apresentam uma estrutura tipicamente xistosa formada por porfiroclastos de feldspato potássico e/ou plagioclásio imersos em uma matriz de quartzo, K-feldspato, plagioclásio e máficos. Em ambas as fácies a matriz apresenta textura granolepidoblástica dominada por cristais recristalizados de quartzo, microclínio, plagioclásio e biotita; tendo opacos, titanita, allanita, sericita, muscovita, epidoto, rutilo e argilo-minerais como minerais acessórios e/ou de alteração. Datação U-Pb em zircão pelo método TIMS realizada por Geraldes et al. (2001) em rochas do Granito Ellus forneceram idades de 1450 a 1430 Ma, interpretadas como de cristalização. Idades modelo Sm-Nd indicam que o protólito magmático sofreu o fracionamento mantélico por volta de 1,5 Ga. Os valores positivos de $\varepsilon_{\mathrm{Nd}(\mathrm{t})}+3,6 \mathrm{e}+3,7$ indicam que os litotipos do Granito Ellus possuem derivação mantélica com assinatura isotópica juvenil.

\section{GEOLOGIA DO GRANITO ENCANTADA}

O Granito Encantada aflora como um corpo alongado na direção norte-sul na região da Fazenda Encantada (Figura 2), com área aproximada de $160 \mathrm{~km}^{2}$. Os principais afloramentos são na forma de matacões e lajedos, os quais definem um relevo movimentado que se destaca em relação à planície do pantanal de Santa Rita (Figura 3).

Em locais onde não ocorrem afloramentos observa-se um solo residual arenoso, rico em quartzo e com fragmentos de muscovita e, mais raramente, caulim oriundo da alteração de feldspatos.

O Granito Encantada aloja-se nas rochas metassedimentares e metavulcânicas do Complexo Metavulcano-Sedimentar Rio Alegre. Evidências dessa relação de contato podem ser observadas ao longo de todo o corpo, principalmente nas bordas noroeste, onde ocorrem xenólitos de rochas metavulcânicas básicas (Figuras 4A e 4B), e sudeste, onde ocorre um megaxenólito de rochas metavulcânicas básicas que pode ser observado no mapa geológico (Figura 2).

Na porção leste do Granito Encantada é possível observar restitos de rochas metassedimentares pelíticas, marcados por cristais residuais, que possivelmente foram poupados no processo de fusão parcial das rochas geradoras do granito (Figura 4C). Na parte norte, na região da Fazenda Ellus, pode-se observar as relações de contato das rochas do Granito Encantada com as rochas do Granito Ellus. Nesta região é possível observar xenólitos das rochas do Granito Encantada de textura equigranular e granulação fina dispersos nas rochas do Granito Ellus, que apresentam textura porfiroclástica e matriz média (Figura 4D). 


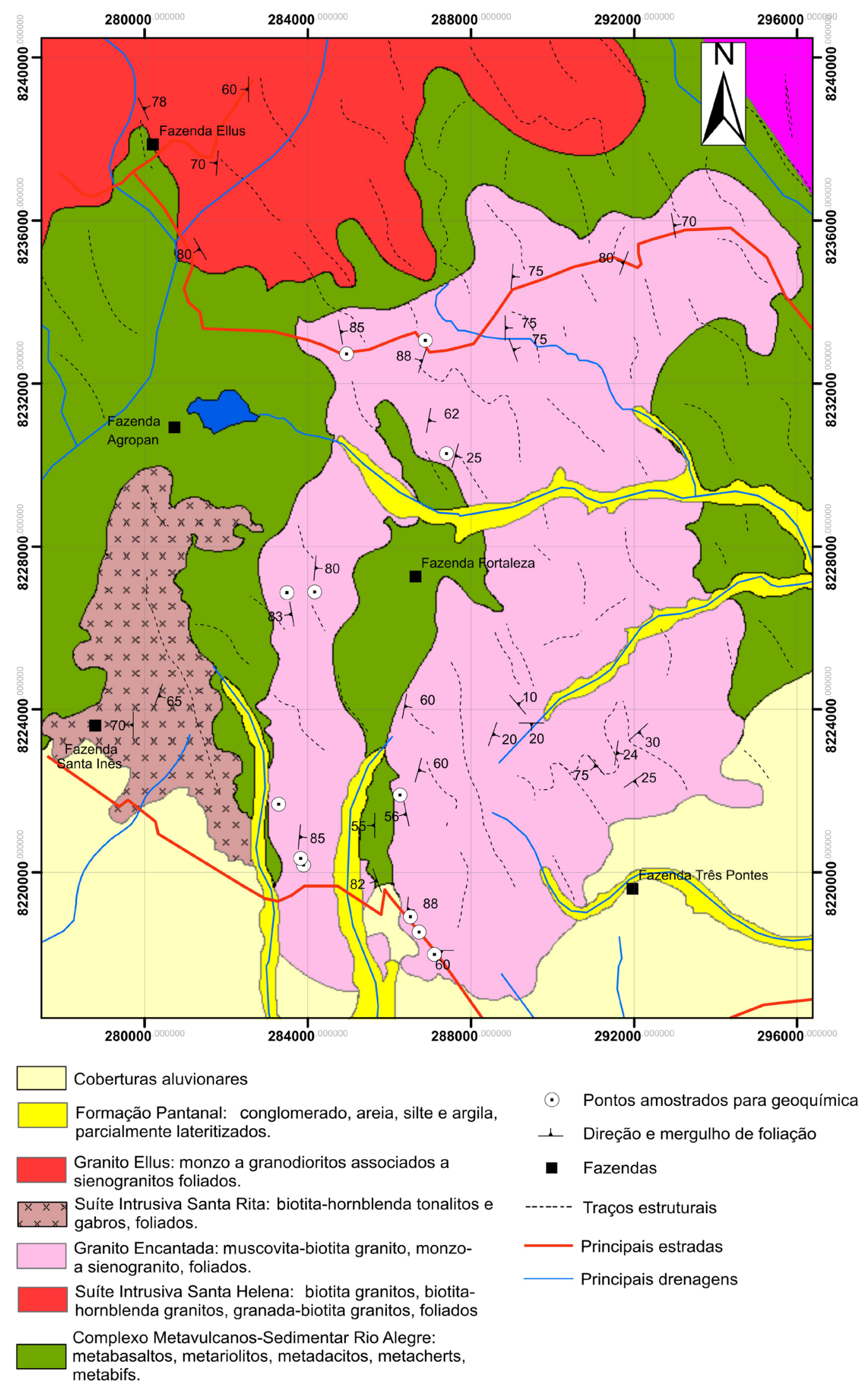

Figura 2. Mapa Geológico da região da Fazenda Encantada situada no SW do estado de Mato Grosso. 

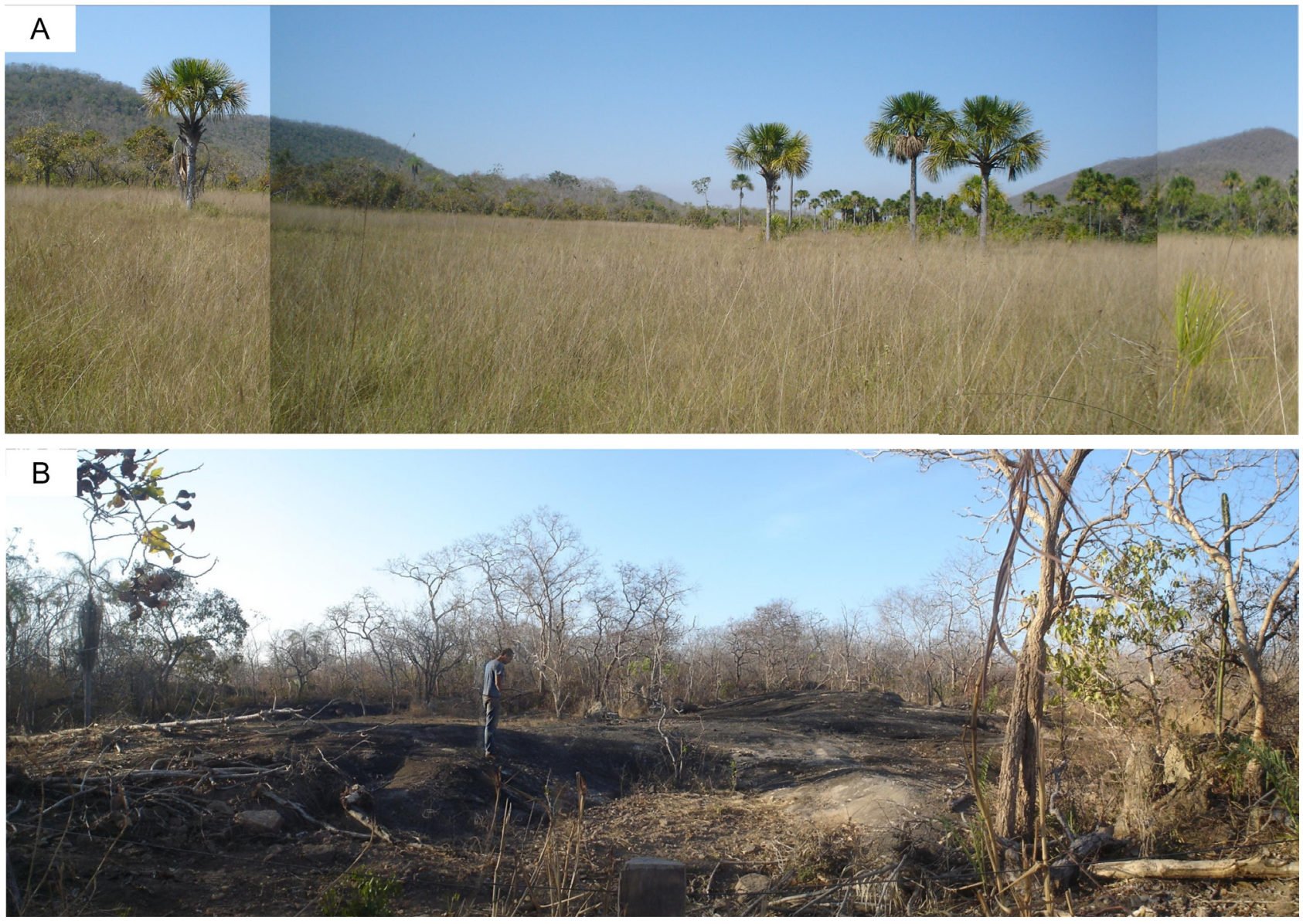

Figura 3. Aspecto geomorfológico e de afloramento das rochas do Granito Encantada. A: Aspecto do relevo associado as rochas do granito Encantada marcado por cristas que se destacam em relação ao relevo suave do Pantanal de Santa Rita; B: Aspecto de afloramento do granito Encantada marcado por lajedo com dimensão aproximada de 100 por 150 m.

Os litotipos do Granito Encantada apresentam dois tipos petrográficos: granitos porfiríticos e granitos finos. Macroscopicamente, os granitos porfiríticos apresentam coloração rosada a rósea acinzentada, com porfiroclastos de feldspato potássico e quartzo imersos em matriz média, composta por feldspato potássico, quartzo, plagioclásio, biotita, muscovita e granada (Figuras 5A e 5B). Os granitos finos apresentam coloração rósea a róseo acinzentado, granulação fina, compostos por feldspato potássico, quartzo, plagioclásio, biotita e muscovita (Figuras 5C e 5D). As rochas de ambas as fácies apresentam uma xistosidade definida por biotita, muscovita e agregados recristalizados de quartzo e plagioclásio (Figuras 5B a 5D). Em ambas as fácies são comuns ocorrências de diques pegmatíticos como os ilustrados nas Figuras 5E e 5F. Esses diques de espessura centimétrica a métrica possuem granulação grossa, sendo compostos por quartzo, feldspato potássico e muscovita.

Pelo microscópio é possível observar que as rochas de ambos os fácies apresentam a mesma associação mineral constituída por feldspato potássico, quartzo, plagioclásio, biotita e muscovita como minerais essenciais, e opacos, apatita, turmalina e monazita como minerais acessórios. A diferença entre as duas fácies é textural. A fácies porfirítica apresenta textura inequigranular, hipidiomórfica a xenomórfica, com porfiroclastos de feldspato potássico, plagioclásio e quartzo imersos em matriz composta essencialmente por quartzo, feldspato potássico, plagioclásio, biotita e muscovita (Figura 6A). A fácies fina apresenta textura inequigranular a equigranular, xenomórfica a hipidiomórfica, onde predomina feldspato potássico, quartzo, plagioclásio, biotita e muscovita (Figura 6B).

Na maior parte das amostras estudadas, plagioclásio, feldspato potássico e quartzo apresentaram quantidades equivalentes, com leve predominância do primeiro sobre os demais. Biotita e muscovita ocorreram em quantidades similares com leve predomínio do primeiro mineral sobre o segundo. Estimativa de proporção modal de quartzo, plagioclásio e feldspato potássico nas rochas do Granito Encantada quando plotadas no diagrama QAP permitiu classificá-lo como um granito e secundariamente granodiorito (Figura 7). 


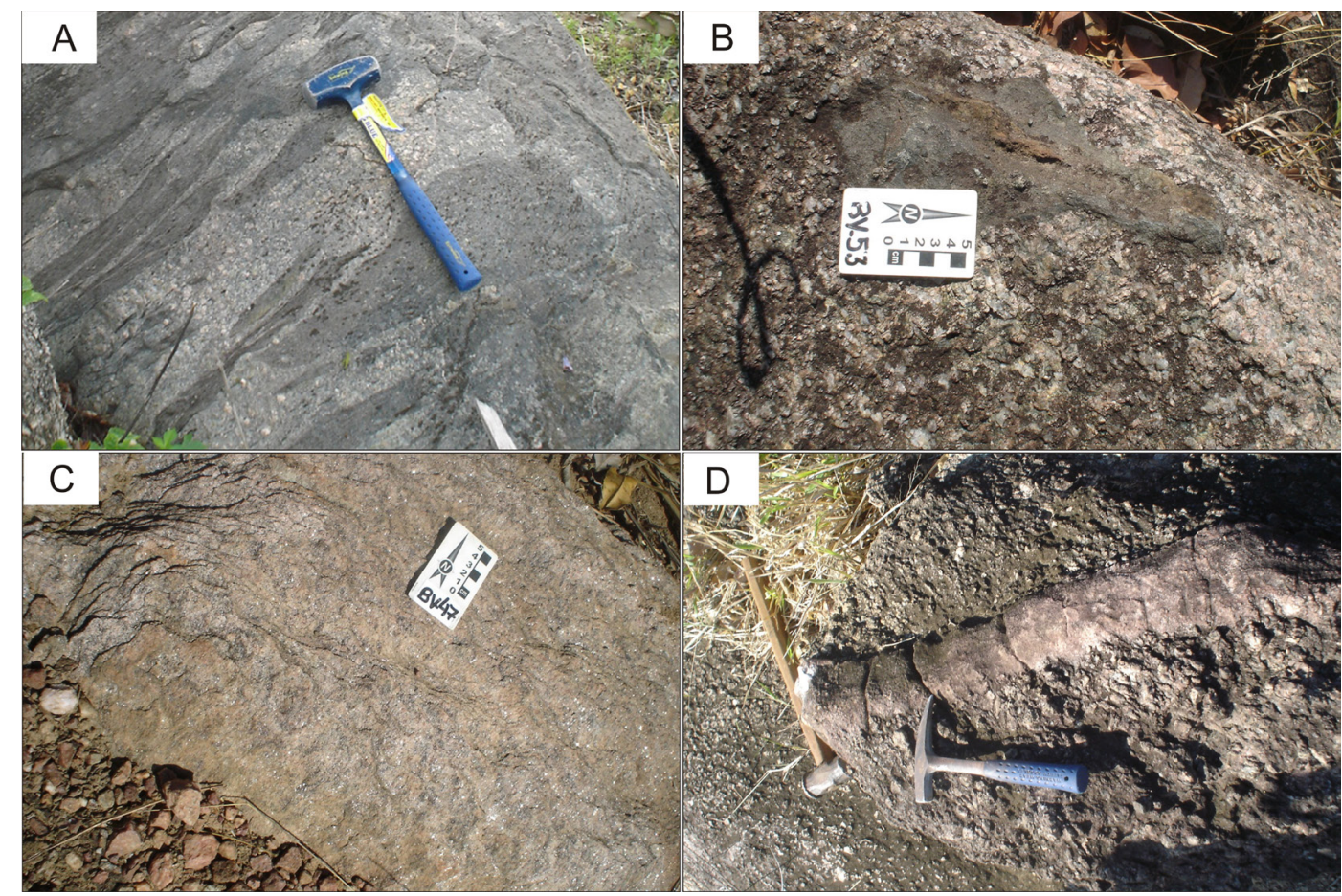

Figura 4. Fotografias de campo ilustrando as relações de corte do Granito Encantada. A: Xenólitos de metadacito dispersos no Granito Encantada, na borda noroeste do corpo, região da Fazenda Agropan; B: Xenólito de anfibolito no Granito Encantada na região da Fazenda Três Pontes, parte sul do corpo; C: Afloramento do granito Encantada com restito de rocha metassedimentar pelítica; D: Afloramento do Granito Ellus com textura porfirítica (porfiroclastos de K-feldspato) no qual ocorre xenólito do Granito Encantada com textura equigranular e granulação fina.

Ambos os fácies apresentam uma foliação que varia de incipiente a pervasiva. Quando presente é definida por muscovita e biotita e nas áreas mais deformadas quartzo e plagioclásio recristalizado (Figuras 5B a 5D).

O feldspato potássico predominante é a microclina, no entanto, são observados cristais de ortoclásio, o que comumente ocorre como cristais subédricos com geminação xadrez, apresentando tamanho variável entre 0,03 e $15 \mathrm{~mm}$. Os porfiroclastos deste mineral, alguns com dimensões acima de $30 \mathrm{~mm}$, podem apresentar um complexo padrão de intercrescimento pertítico identificado como dos tipos striglets, strings ou interlocking (Deer et al., 2004). Por vezes a quantidade de plagioclásio é tão grande que é difícil distinguir o hóspede do hospedeiro (Figura 6C). É comum os porfiroclastos de microclina conterem inclusões irregularmente distribuídas de quartzo, plagioclásio, muscovita e biotita, o que por vezes confere aos grãos aspecto poiquilítico. Alguns cristais exibem fraturas, algumas das quais preenchidas por quartzo, denunciando processos deformacionais rúpteis (Figura 6D).

O quartzo apresenta-se em grãos anédricos intersticiais, podendo ocorrer como inclusões em feldspatos ou ainda como porfiroclastos. Seu diâmetro médio varia de 0,3 a $1,0 \mathrm{~mm}$, podendo alcançar $20 \mathrm{~mm}$. Quando incluso, é geralmente menor que $0,2 \mathrm{~mm}$. Nas zonas de maior deformação apresenta extinção ondulante, lamelas e bandas de deformação ou ribbons. É comum a ocorrência de diminutos grãos recristalizados nas margens de porfiroclastos, indicando processos de deformação intracristalina.

O plagioclásio, classificado como oligoclásio a partir do método estatístico Michel-Levy, apresenta dimensões variadas normalmente entre 0,5 e $2 \mathrm{~mm}$, hábito euédrico a anédrico, com geminação polissintética, combinada Carlsbadpolissintética e periclina, sendo comuns de cristais sem geminação. São comuns inclusões de quartzo e muscovita aleatoriamente distribuídas. Normalmente os cristais de plagioclásio ocorrem saussuritizados (Figura 6E). Nas rochas mais deformadas o plagioclásio mostra extinção ondulante, com limites de grão irregulares e neoformação de cristais, denunciando processo de deformação intracristalina.

A muscovita ocorre em palhetas tabulares euédricas a subédricas, algumas vezes como porfiroblastos, comumente em agregados. Alguns cristais podem mostrar seções límpidas sem inclusões (Figuras 6F a 6H). Possui dimensões variadas entre 0,05 e 2,0 mm, com exemplares de até $5 \mathrm{~mm}$, tamanho comparável ao dos outros componentes ígneos. Estas características indicam que a muscovita tem origem ígnea segundo os critérios texturais sugeridos por Miller et al. (1981). 

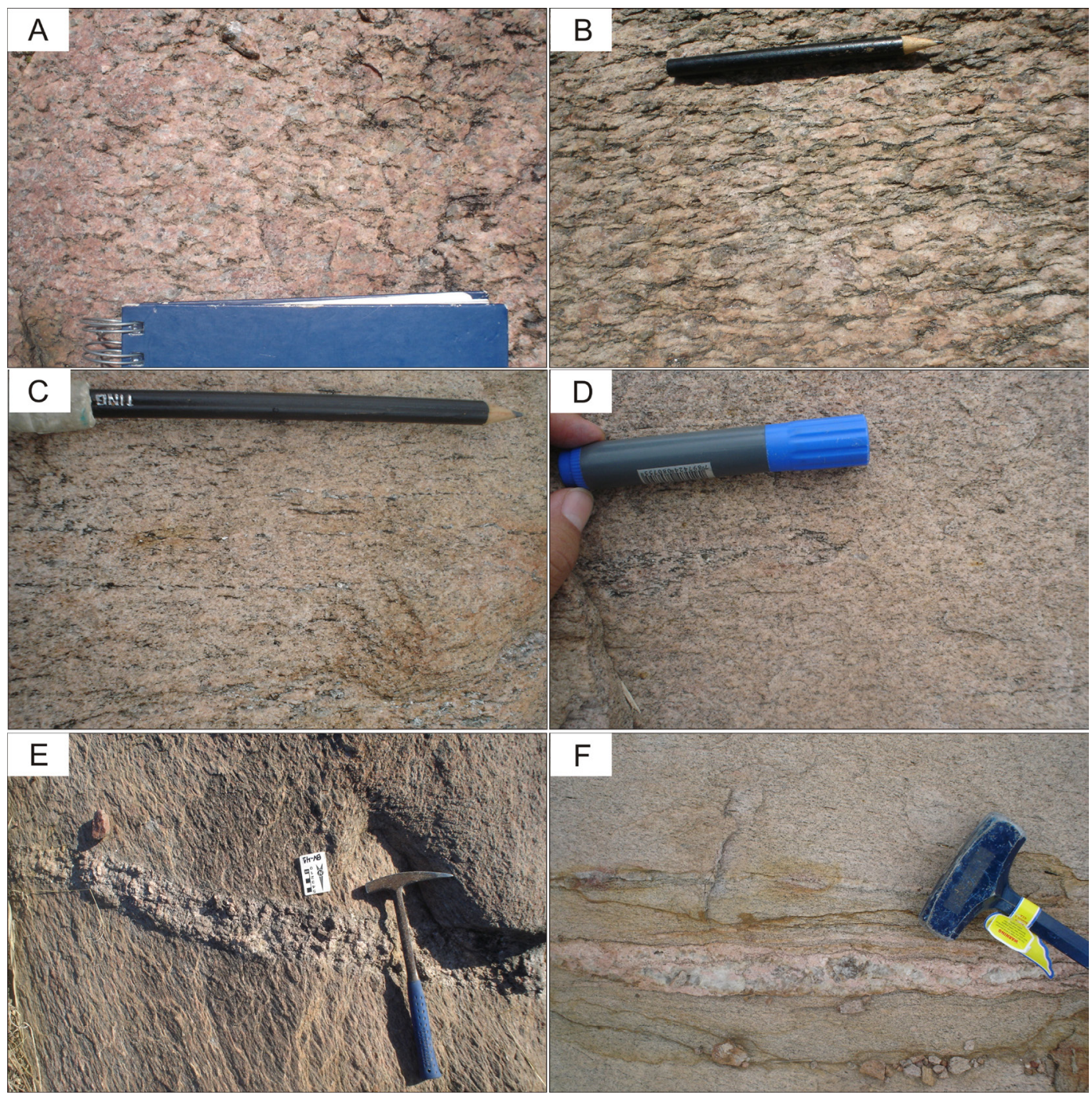

Figura 5. Aspectos texturais das rochas do Granito Encantada. A e B: fácies porfirítica, a qual apresenta matriz média composta por feldspato potássico, quartzo, plagioclásio, biotita e muscovita, com porfiroclastos de feldspato potássico e quartzo. Na foto A a foliação é fraca, já na foto B o granito apresenta uma xistosidade definida pela muscovita, biotita e por agregados recristalizados de quartzo e plagioclásio. C e D: apresentam o aspecto da fácies fina do granito, o qual apresenta textura equigranular, com granulação fina a média, com quartzo, K-feldspato, plagioclásio, muscovita e biotita. É comum a ocorrência de restitos constituídos essencialmente por muscovita como os observados na parte central da foto D. E e F: diques pegmatíticos intrusivos nas fácies porfirítica e fina respectivamente.

A muscovita também ocorre inclusa nos feldspatos como cristais, neste caso de origem secundária.

A biotita ocorre em palhetas tabulares relativamente bem terminadas, com dimensões compreendidas entre 0,05 e 2,0 $\mathrm{mm}$ (Figura 6G). Apresenta forte pleocroísmo, que varia de verde a castanho. Por vezes pode ser encontrada parcial a totalmente alterada para clorita ou muscovita, algumas vezes constituindo agregados que dispõem forte orientação.

Os minerais acessórios mais comuns são opacos, apatita, turmalina e granada, que ocorrem dispersos na matriz com os minerais essenciais. Os opacos ocorrem dispersos em grãos anédricos, por vezes parcialmente desopacitizados. A apatita é um acessório comum podendo ocorrer em cristais euédricos a subédricos associados à muscovita e biotita. A turmalina ocorre em cristais isolados intersticiais ou inclusa em plagioclásio, K-feldspato e quartzo. Possui dimensões inferiores a $0,5 \mathrm{~mm}$, apresentando zonação bem definida, com núcleo arredondado verde e borda verde alarajado bem formada. A granada é pouco frequente; quando presente ocorre em forma anédrica a subédrica, por vezes esqueletal ou intersticial, com tamanho médio de 0,5 mm (Figura 6H). A titanita pode ocorrer como fase primária em cristais romboédricos 

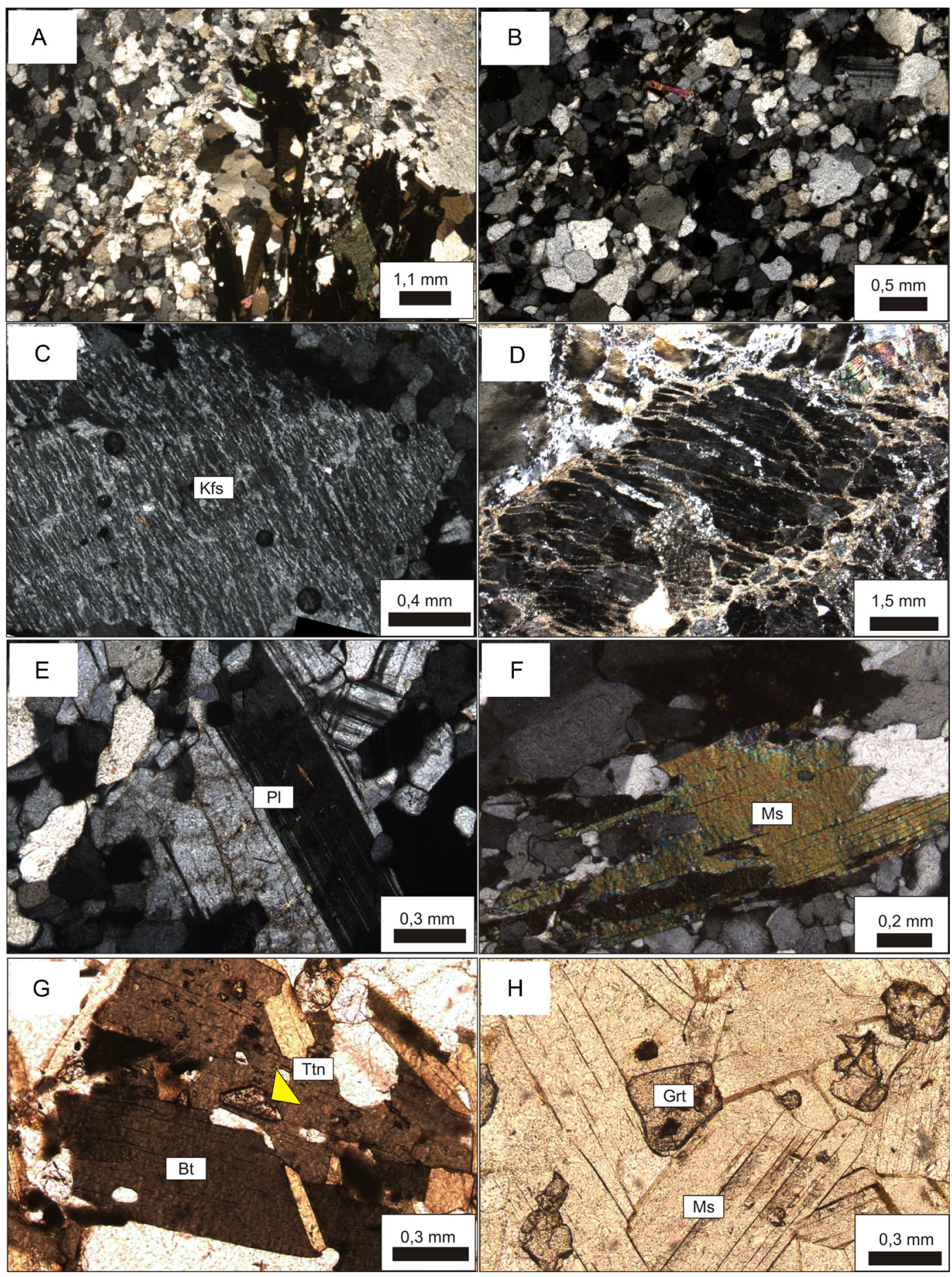

Figura 6. Fotomicrografias do Granito Encantada. A: Aspecto da fácies porfirítica do granito, com uma matriz média constituída por quartzo, plagioclásio, biotita e muscovita, envolvendo cristais de K-feldspato; B: Aspecto da fácies fina composta por quartzo, plagioclásio, biotita, muscovita, e K-feldspato; C: Porfiroclasto de K-feldspato com intercrescimento pertítico, no qual a quantidade de plagioclásio é tão grande que é difícil distinguir o hóspede do hospedeiro; D: Porfiroclasto de K-feldspato com fraturas preenchidas por quartzo; E: Porfiroclasto de plagioclásio com forma subédrica, intensamente saussuritizado, disperso em matriz de granulação fina constituída por quartzo, K-feldspato e plagioclásio; F: Palheta subédrica de muscovita com tamanho similar ao da matriz composto por quartzo e plagioclásio; G: Palhetas subédricas de biotita com inclusões de euédricas de titanita; H: Palheta subédrica de muscovita associados a granada. 
associados à muscovita e/ou biotita (Figura 6G), ou secundária em grãos anédricos associados à biotita ou aos opacos.

Os minerais secundários e de alteração mais comuns são serecita, epidoto e allanita, produto da alteração da biotita e do plagioclásio. A allanita é comum exibindo-se em cristais euédricos com textura coronítica formada por epidoto e/ou biotita.

\section{GEOQUÍMICA DO GRANITO ENCANTADA}

A caracterização geoquímica do Granito Encantada foi feita com base em 13 amostras representativas de todo o corpo, cuja localização é apresentada no Mapa Geológico (Figura 2). As composições das rochas em termos de elementos maiores (\%) e traços (ppm), incluindo terras raras, são apresentadas na Tabela 1.

As análises foram realizadas no ACME Analytical Laboratories (ACMELAB). O comportamento dos elementos maiores e de alguns elementos traços $(\mathrm{Zr}, \mathrm{Sr}, \mathrm{Rb}$, e $\mathrm{Ba}$ ) pode ser visualizado nos diagramas de Harker (Figuras 8 e 9).

Os altos teores de sílica entre 71,22 e 77,54\% caracterizam o Granito Encantada como uma sequência ácida pouco expandida, sugerindo evolução contínua marcada por cristalização fracionada. Correlações lineares negativas entre $\mathrm{SiO}_{2}$ e $\mathrm{Al}_{2} \mathrm{O}_{3}, \mathrm{Fe}_{2} \mathrm{O}_{3}, \mathrm{CaO}, \mathrm{MgO}, \mathrm{TiO}_{2}, \mathrm{P}_{2} \mathrm{O}_{5}, \mathrm{Na}_{2} \mathrm{O}, \mathrm{K}_{2} \mathrm{O}, \mathrm{Zr}, \mathrm{Sr}$, e $\mathrm{Ba}$ podem ser explicadas pelo empobrecimento progressivo durante a diferenciação em plagioclásio cálcico e em minerais máficos primários, tais como biotita, muscovita, titanita, ilmenita, granada, apatita e zircão. Correlação linear positiva é observada para o $\mathrm{Rb}$, o que também pode estar ligado à cristalização fracionada, pois o tamanho iônico de $\mathrm{Rb}$ é relativamente maior do que o de K. Este tende a ter uma energia de ligação mais elevada com $\mathrm{O}$ do que com o $\mathrm{Rb}$; dessa forma, o K é cristalizado em minerais enquanto o $\mathrm{Rb}$ permanece líquido, tendendo a concentrar-se nos magmas residuais (Imeokparia, 1981).

Os valores de $\mathrm{Sr}(12-157 \mathrm{ppm})$ são baixos, semelhantes ao esperado para magmas graníticos que foram produzidos através da fusão parcial de rochas crustais em temperaturas baixas, como visto na Figura 9 (Wilson, 1989; Patiño-Douce e Johnston, 1991; Patiño- Douce, 1999).

A partir dos diagramas $\mathrm{Na}_{2} \mathrm{O}+\mathrm{K}_{2} \mathrm{O}$ versus sílica de Cox et al. (1979), na Figura 10A, e Zr/TiO ${ }_{2}^{*} 0,0001$ versus sílica de Winchester e Floyd (1977), na Figura 10B, usualmente utilizados para classificação das rochas ígneas, as rochas do Granito Encantada foram classificadas como "granitos".

Frost et al. (2001) propuseram um esquema de classificação baseado na relação $\mathrm{FeO} /(\mathrm{FeO}+\mathrm{MgO})$, segundo a qual as rochas do Granito Encantada podem ser associados aos granitos ferrosos (Figura 10C). Outra classificação proposta por Frost et al. (2001) baseia-se no índice de alcalinidade modificado $\left(\mathrm{Na}_{2} \mathrm{O}+\mathrm{K}_{2} \mathrm{O}-\mathrm{CaO}\right)$. Neste caso, as rochas

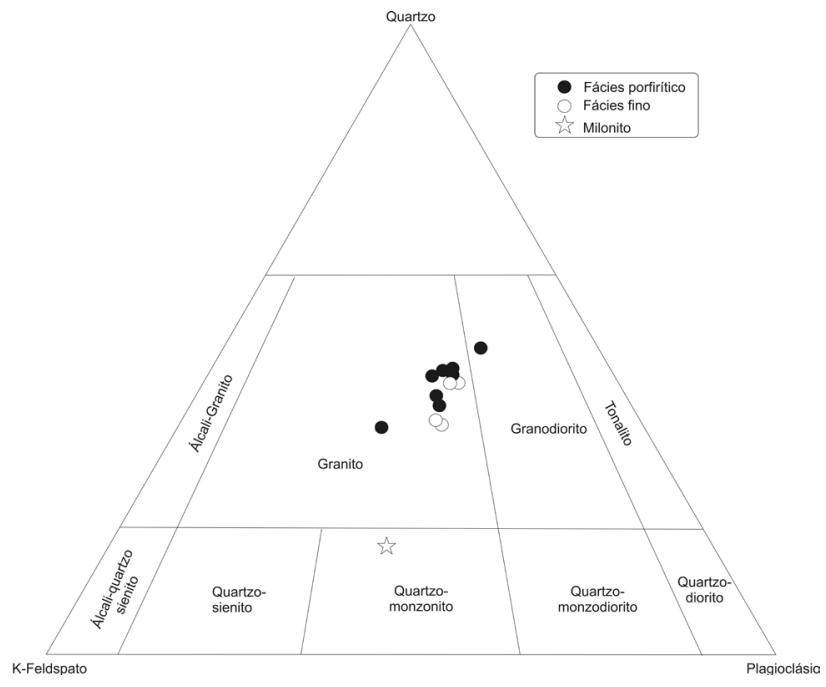

Figura 7. Diagrama QAP para classificação de granitos segundo Streickesen (1973).

estudadas são classificadas como granitos cálcio-alcalinos e alcalino-cálcicos (Figura 10D).

O magmatismo que originou o Granito Encantada é classificado como subalcalino do tipo cálcio-alcalino, como observado nos diagramas propostos por Irvine e Baragar (1971), que consideram o teor de álcalis versus $\mathrm{SiO}_{2}$ (Figura 10E), e AFM (Figura 10F), respectivamente. Neste último, é possível observar que as amostras do Granito Encantada descrevem um trend aproximadamente linear que evolui em direção ao vértice dos álcalis, situando-se sobre a linha $\mathrm{FeO}$-álcalis. A natureza cálcio-alcalina de alto $\mathrm{K}$ é ilustrada na Figura $10 \mathrm{G}\left(\mathrm{K}_{2} \mathrm{O}\right.$ versus $\left.\mathrm{SiO}_{2}\right)$, de acordo com Cox et al. (1979), com algumas amostras tendendo ao campo das rochas shoshoníticas. Quanto à saturação de alumina, esse magma é peraluminoso, conforme indica o diagrama $\mathrm{A} /$ NK e A/CNK de Maniar e Piccoli (1989) na Figura 10H.

A Figura $11 \mathrm{~A}$ apresenta as principais séries magmáticas e produtos de fusão crustal em um diagrama de $\mathrm{CaO}+\mathrm{K}_{2} \mathrm{O}$ versus sílica (TAS), de acordo com Le Maitre (2002). Neste diagrama, as amostras do Granito Encantada plotam no campo da "associação leucocrática peraluminosa". Quando se leva em consideração os elementos Th e Co (Hastie et al., 2007), como vemos na Figura 11B, os dados do Granito Encantada coincidem com o campo dos dioritos/riodacitos da série cálcio alcalina de alto K, corroborando o tipo de magmatismo definido pelo diagrama de Peccerillo e Taylor (1976) da Figura 10G.

Os padrões de Elementos Terras Raras (ETR) normalizados pelos valores condríticos de Nakamura (1977) na Figura 12A são homogêneos, com inclinação negativa muito suave, sugerindo que as rochas estudadas são cogenéticas.

Apresentam leve enriquecimento dos ETR leves (La, $\mathrm{Ce}, \mathrm{Pr}, \mathrm{Nd}$ e $\mathrm{Sm}$ ) em relação aos elementos terras raras pesados (Dy, Ho, Er, Tm, Yb e Lu), com 
Tabela 1. Composição química de elementos maiores, menores (\% em peso), traços e terras raras (ppm) de rochas do Granito Encantada.

\begin{tabular}{|c|c|c|c|c|c|c|c|c|c|c|c|c|c|}
\hline Elemento & 01 & 02 & 03 & 04 & $05 \mathrm{~A}$ & 05B & 06B & 07 & $11 \mathrm{~A}$ & 11B & 12 & 12B & 13 \\
\hline $\mathrm{SiO}_{2}$ & 77,54 & 76,12 & 75,08 & 76,22 & 75,85 & 74,79 & 74,95 & 76,35 & 74,18 & 75,47 & 71,85 & 76,49 & 71,22 \\
\hline $\mathrm{TiO}_{2}$ & 0,09 & 0,10 & 0,13 & 0,10 & 0,10 & 0,19 & 0,18 & 0,07 & 0,21 & 0,06 & 0,33 & 0,09 & 0,28 \\
\hline $\mathrm{Al}_{2} \mathrm{O}_{3}$ & 11,44 & 12,30 & 12,79 & 12,27 & 12,62 & 12,80 & 12,63 & 12,69 & 12,93 & 13,54 & 13,79 & 12,26 & 14,39 \\
\hline $\mathrm{Fe}_{2} \mathrm{O}_{3}$ & 1,88 & 1,95 & 1,97 & 1,82 & 1,51 & 2,07 & 2,03 & 1,72 & 2,50 & 1,06 & 3,06 & 1,43 & 2,84 \\
\hline $\mathrm{MnO}$ & 0,03 & 0,03 & 0,05 & 0,04 & 0,02 & 0,03 & 0,03 & 0,03 & 0,04 & 0,02 & 0,05 & 0,02 & 0,08 \\
\hline $\mathrm{MgO}$ & 0,03 & 0,16 & 0,15 & 0,03 & 0,06 & 0,15 & 0,16 & 0,04 & 0,18 & 0,04 & 0,33 & 0,09 & 0,29 \\
\hline $\mathrm{CaO}$ & 0,44 & 0,61 & 0,71 & 0,47 & 0,70 & 0,88 & 0,66 & 0,23 & 0,76 & 0,38 & 1,24 & 0,31 & 0,74 \\
\hline $\mathrm{Na}_{2} \mathrm{O}$ & 3,21 & 3,44 & 3,55 & 3,65 & 3,52 & 3,25 & 3,27 & 3,42 & 3,12 & 3,89 & 3,29 & 2,81 & 4,49 \\
\hline $\mathrm{K}_{2} \mathrm{O}$ & 4,87 & 4,81 & 4,92 & 4,94 & 5,17 & 5,22 & 5,38 & 4,75 & 5,55 & 5,40 & 5,41 & 5,94 & 4,88 \\
\hline $\mathrm{P}_{2} \mathrm{O}_{5}$ & 0,02 & 0,01 & 0,03 & 0,02 & 0,02 & 0,06 & 0,03 & 0,15 & 0,04 & 1,00 & 0,07 & 0,02 & 0,08 \\
\hline LOI & 0,40 & 0,40 & 0,50 & 0,40 & 0,40 & 0,40 & 0,60 & 0,50 & 0,30 & 0,10 & 0,40 & 0,50 & 0,50 \\
\hline Total & 99,95 & 99,93 & 99,88 & 99,96 & 99,97 & 99,84 & 99,92 & 99,95 & 99,81 & 100,96 & 99,82 & 99,96 & 99,79 \\
\hline $\mathrm{Ba}$ & 149 & 143 & 326 & 28 & 215 & 574 & 479 & 14 & 696 & 155 & 1128 & 267 & 916 \\
\hline Cs & 3,8 & 1,9 & 5,1 & 4,0 & 1,6 & 2,0 & 1,4 & 2,1 & 2,9 & 1,4 & 2,8 & 0,8 & 1,4 \\
\hline $\mathrm{Ga}$ & 19,1 & 18,2 & 19,1 & 22,2 & 17,6 & 17,4 & 16,4 & 22 & 19,5 & 21,4 & 18,3 & 16,7 & 20,3 \\
\hline $\mathrm{Hf}$ & 6,5 & 5,9 & 6,6 & 7 & 4,9 & 5,6 & 5,3 & 7,4 & 8,2 & 4,8 & 8,4 & 6,2 & 9,8 \\
\hline $\mathrm{Nb}$ & 22,7 & 27,6 & 19,7 & 30,9 & 16 & 12,1 & 11 & 27,3 & 17,5 & 21,4 & 23,9 & 10,8 & 30,4 \\
\hline $\mathrm{Rb}$ & 232,2 & 224,1 & 259,5 & 263,1 & 225,7 & 164,8 & 168 & 334,1 & 212,8 & 217,6 & 197,6 & 155,9 & 229,2 \\
\hline $\mathrm{Sr}$ & 19,5 & 28,9 & 82,2 & 12,9 & 37,1 & 85,3 & 76,3 & 10,5 & 104,3 & 39,7 & 157,7 & 37,9 & 105 \\
\hline $\mathrm{Ta}$ & 5 & 0 & 1 & 2,1 & & 1 & ᄀ & 2 , & & 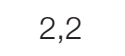 & & 0,7 & ,5 \\
\hline Th & , & 23,8 & 20,8 & 17,8 & & 12 & & Us, & & & & & 20,7 \\
\hline$U$ & & & 6,3 & 5,5 & & 6,4 & & 13,3 & & & & & 5,3 \\
\hline $\mathrm{Zr}$ & 154,2 & 127,7 & 149,4 & 139,7 & 135,7 & 179,1 & 163,4 & 157,4 & 238,4 & 88,8 & 311,7 & 146,6 & 325,5 \\
\hline Y & 105,6 & 95,3 & 75,4 & 91,4 & 80,2 & 169,2 & 53,6 & 85,4 & 170,9 & 111,4 & 72,2 & 48 & 101,6 \\
\hline $\mathrm{La}$ & 57,2 & 48,9 & 50,6 & 32 & 57 & 178,4 & 54,1 & 26,7 & 188,3 & 38,9 & 54,7 & 12,7 & 84,4 \\
\hline $\mathrm{Ce}$ & 124,5 & 84,2 & 105,1 & 67,3 & 119,5 & 164 & 114,5 & 103,5 & 217,5 & 64,8 & 123,8 & 94,7 & 180,1 \\
\hline $\operatorname{Pr}$ & 16,35 & 13,43 & 12,25 & 7,59 & 13,84 & 41,09 & 13,55 & 7,62 & 41,52 & 10,98 & 14,6 & 3,79 & 20,43 \\
\hline $\mathrm{Nd}$ & 67,3 & 53 & 48,5 & 30,1 & 49,7 & 170,3 & 50,7 & 30,6 & 168,6 & 47,4 & 59 & 15,1 & 74,2 \\
\hline $\mathrm{Sm}$ & 14,82 & 11,14 & 8,68 & 6,39 & 8,85 & 28,63 & 8,24 & 6,93 & 27,78 & 11,23 & 11,25 & 3,79 & 13,09 \\
\hline $\mathrm{Eu}$ & 0,59 & 0,43 & 0,47 & 0,11 & 0,35 & 2,39 & 0,57 & 0,07 & 2,67 & 0,63 & 1,29 & 0,13 & 1,29 \\
\hline Gd & 16,12 & 11,25 & 8,46 & 7,91 & 8,37 & 30,27 & 7,41 & 7,57 & 28,41 & 12,33 & 10,56 & 4,79 & 12,17 \\
\hline $\mathrm{Tb}$ & 3,02 & 2,15 & 1,58 & 1,66 & 1,6 & 4,85 & 1,3 & 1,72 & 4,63 & 2,38 & 1,93 & 1,12 & 2,28 \\
\hline Dy & 18,96 & 14,08 & 9,77 & 12,25 & 10,87 & 28,08 & 8,18 & 12,24 & 26,93 & 15,54 & 12,49 & 8,01 & 15,04 \\
\hline $\mathrm{Ho}$ & 3,92 & 3,25 & 2,17 & 2,93 & 2,47 & 5,55 & 1,8 & 2,93 & 5,66 & 3,37 & 2,65 & 1,86 & 3,35 \\
\hline Er & 11,19 & 10,48 & 6,87 & 9,75 & 7,92 & 16,21 & 5,66 & 10,04 & 16,71 & 11,4 & 8,06 & 5,97 & 11 \\
\hline Tm & 1,6 & 1,61 & 1,08 & 1,59 & 1,25 & 2,35 & 0,84 & 1,63 & 2,48 & 1,89 & 1,3 & 0,94 & 1,72 \\
\hline $\mathrm{Yb}$ & 11,43 & 12,01 & 7,87 & 11,71 & 9,16 & 16,29 & 6,02 & 11,85 & 16,95 & 14,21 & 9,71 & 6,6 & 12,91 \\
\hline Lu & 1,64 & 1,82 & 1,24 & 1,88 & 1,39 & 2,36 & 0,94 & 1,82 & 2,66 & 2,06 & 1,37 & 0,9 & 1,94 \\
\hline
\end{tabular}



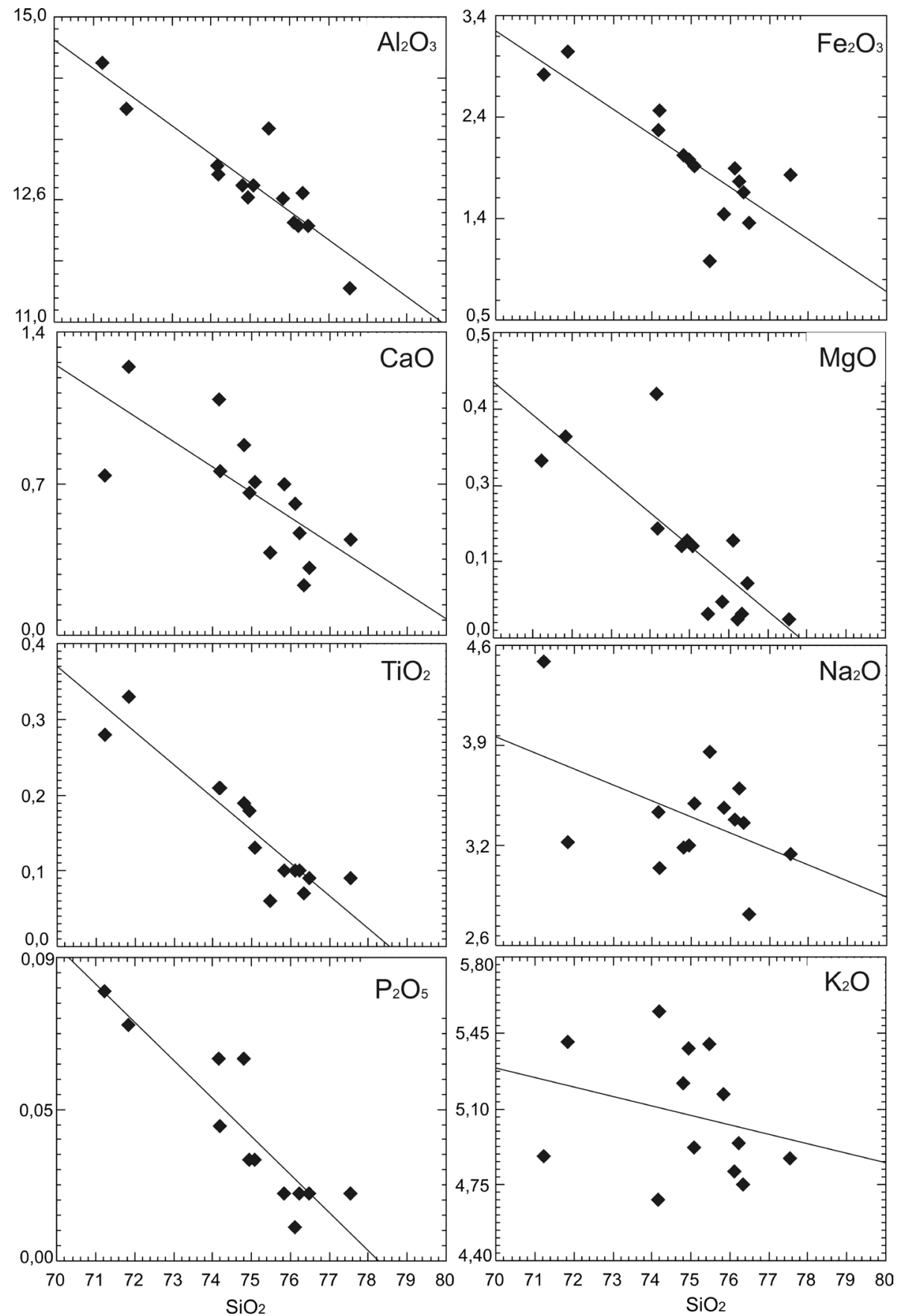

Figura 8. Diagramas de Harker (elementos maiores, expressos em óxidos) para rochas do Granito Encantada.

anomalia negativa de európio, podendo indicar ambiente redutor ou abundância de plagioclásio em fase residual. $\mathrm{O}$ enriquecimento dos ETR leves sobre os pesados corrobora a presença de granada nesses granitos.

A Figura 12B representa um diagrama multielementar para as rochas estudadas, com dados normalizados pela crosta continental. Em geral o diagrama mostra semelhança para padrões de granitos típicos de crosta, neste caso com ausência de inclinação e com valores próximos à unidade. Apenas duas amostras apresentam forte anomalia negativa de bário, provavelmente em razão da menor concentração de potássio nas mesmas. Os valores de estrôncio, em todas as amostras, mostram anomalias negativas, possivelmente em resposta ao fracionamento do plagioclásio. O suave aumento na concentração de cério pode estar associado aos granitos oxidados, oriundos de fusão de crosta. Para os 

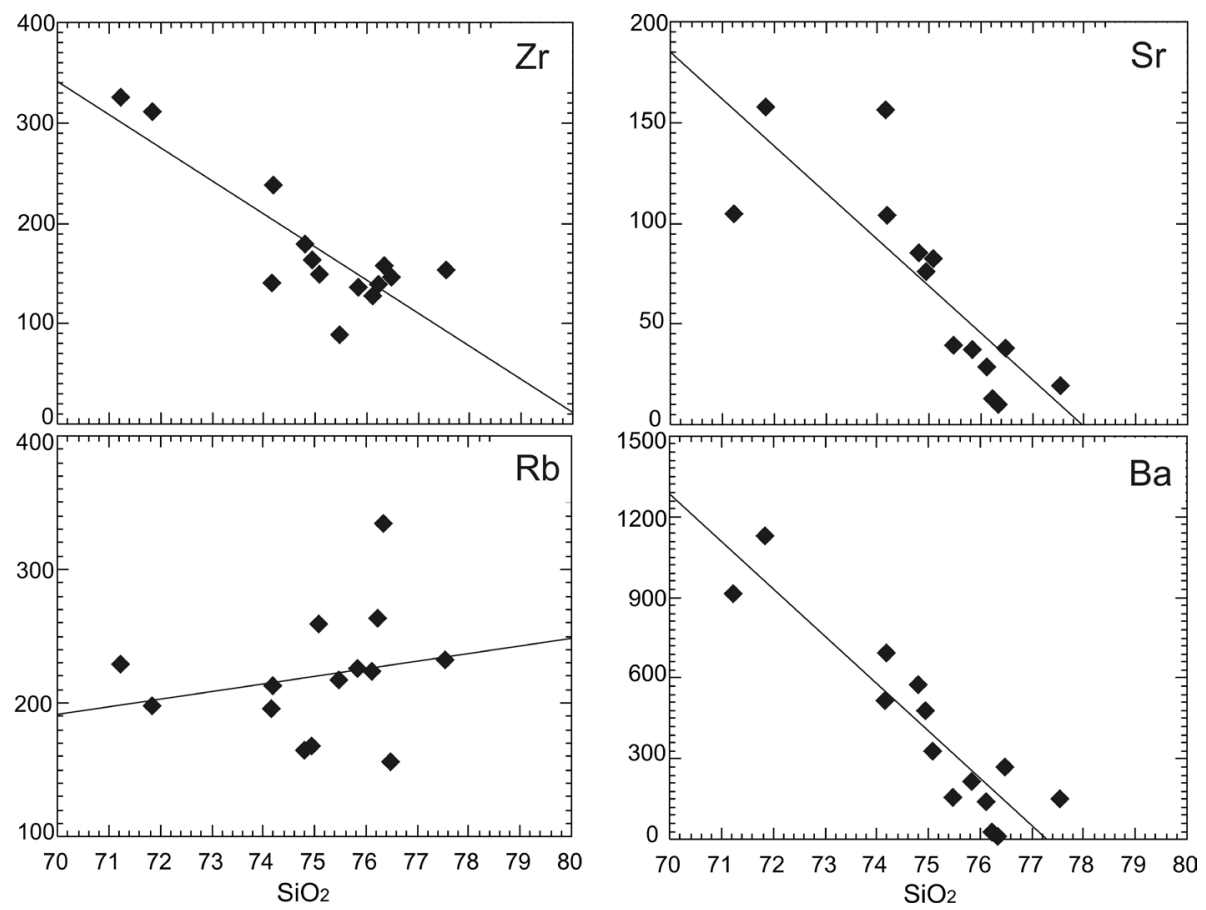

Figura 9. Diagramas de Harker (elementos traços, expressos em ppm) para exemplares do Granito Encantada.

demais elementos, os espectros são praticamente coincidentes, refletindo dados coerentes para amostras cogenéticas.

Pearce et al. (1984), e posteriormente Pearce (1996), propuseram um diagrama que utiliza os elementos $\mathrm{Y}, \mathrm{Nb}$ $\mathrm{e} \mathrm{Rb}$ para discriminar ambientes tectônicos. Os autores basearam seus estudos em dados de rochas de ambientes tectônicos conhecidos e de idade Fanerozoica. No diagrama discriminante $\mathrm{Rb}$ versus $\mathrm{Y}+\mathrm{Nb}$ (Figura 13A), a maior parte das amostras do Granito Encantada estão incluídas no campo dos granitoides pós-colisionais, com algumas plotadas no campo dos granitos gerados em ambiente intraplaca.

Harris et al. (1986) propôs uma classificação de ambientes tectônicos para rochas graníticas baseada no conteúdo de Hf-Rb-Ta (Figura 13B). As rochas do Granito Encantada plotam no campo dos granitos gerados em ambientes de arco vulcânico e pós-colisional.

A avaliação dos protólitos que geram o magmatismo peraluminoso pode ser feita com base na composição litogeoquímica dos granitos. Sylvester (1998) sugere a utilização do diagrama $\mathrm{Al}_{2} \mathrm{O}_{3} / \mathrm{TiO}_{2}$ versus $\mathrm{CaO} / \mathrm{Na}_{2} \mathrm{O}$ (Figura 14) para separar os leucogranitos gerados a partir da fusão de rochas pelíticas daqueles oriundos da fusão de rochas máficas.

Neste diagrama as amostras do Granito Encantada situamse no campo dos granitos fortemente peraluminosos, mais precisamente nas proximidades do ponto de fusão dos pelitos. Com base em uma revisão de dados experimentais de fusão de metapelitos, metarenitos, tonalitos e anfibolitos/eclogitos, Jung e Pfänder (2007) propuseram a utilização das razões $\mathrm{CaO}$ /
$\mathrm{Na}_{2} \mathrm{O}$ e $\mathrm{Al}_{2} \mathrm{O}_{3} / \mathrm{TiO}_{2}$ para identificação dos protólitos de rochas graníticas peraluminosas. Estes autores deduziram que rochas razões $\mathrm{CaO} / \mathrm{Na}_{2} \mathrm{O}$ menores que 0,5 são originadas da fusão de rochas pelíticas; rochas com razões $\mathrm{CaO} / \mathrm{Na}_{2} \mathrm{O}$ entre 0,3 e 1,5 são oriundas de rochas que seriam originados a partir da fusão de grauvacas ou corpos ígneos; já rochas com razões entre 0,1 e 3 (podendo atingir 10) seriam originadas a partir de anfibolito. As baixas razões de $\mathrm{CaO} / \mathrm{Na}_{2} \mathrm{O}$, entre 0,07 e 0,37 , indicam que as rochas do Granito Encantada foram originadas provavelmente pela fusão de rochas pelíticas.

Estimativas da temperatura de cristalização do Granito Encantada podem ser feitas a partir das análises geoquímicas. Hanchar e Watson (2003), a partir das revisões de dados experimentais de temperatura, propuseram a utilização do conteúdo de elementos maiores e $\mathrm{Zr}$ para estimar as temperaturas magmáticas próximas daquelas do liquidus. Utilizando essa técnica, pode-se calcular a temperatura de saturação de zircão para o Granito Encantada entre 739 e $846^{\circ} \mathrm{C}$ (Tabela 2).

Outra técnica aplicada às rochas estudadas foi a proposta de Jung e Pfänder (2007), que utiliza a razão $\mathrm{Al}_{2} \mathrm{O}_{3} / \mathrm{TiO}_{2}$ para cálculo da temperatura. Nesta técnica as temperaturas estimadas variam entre $671 \mathrm{e} 956^{\circ} \mathrm{C}$, sendo os valores mais frequentes entre $800-840{ }^{\circ} \mathrm{C}$ (Tabela 2).

\section{CONSIDERAÇÕES FINAIS}

O Granito Encantada corresponde a um corpo orientado segundo direção NNW, que intrudiu as rochas 

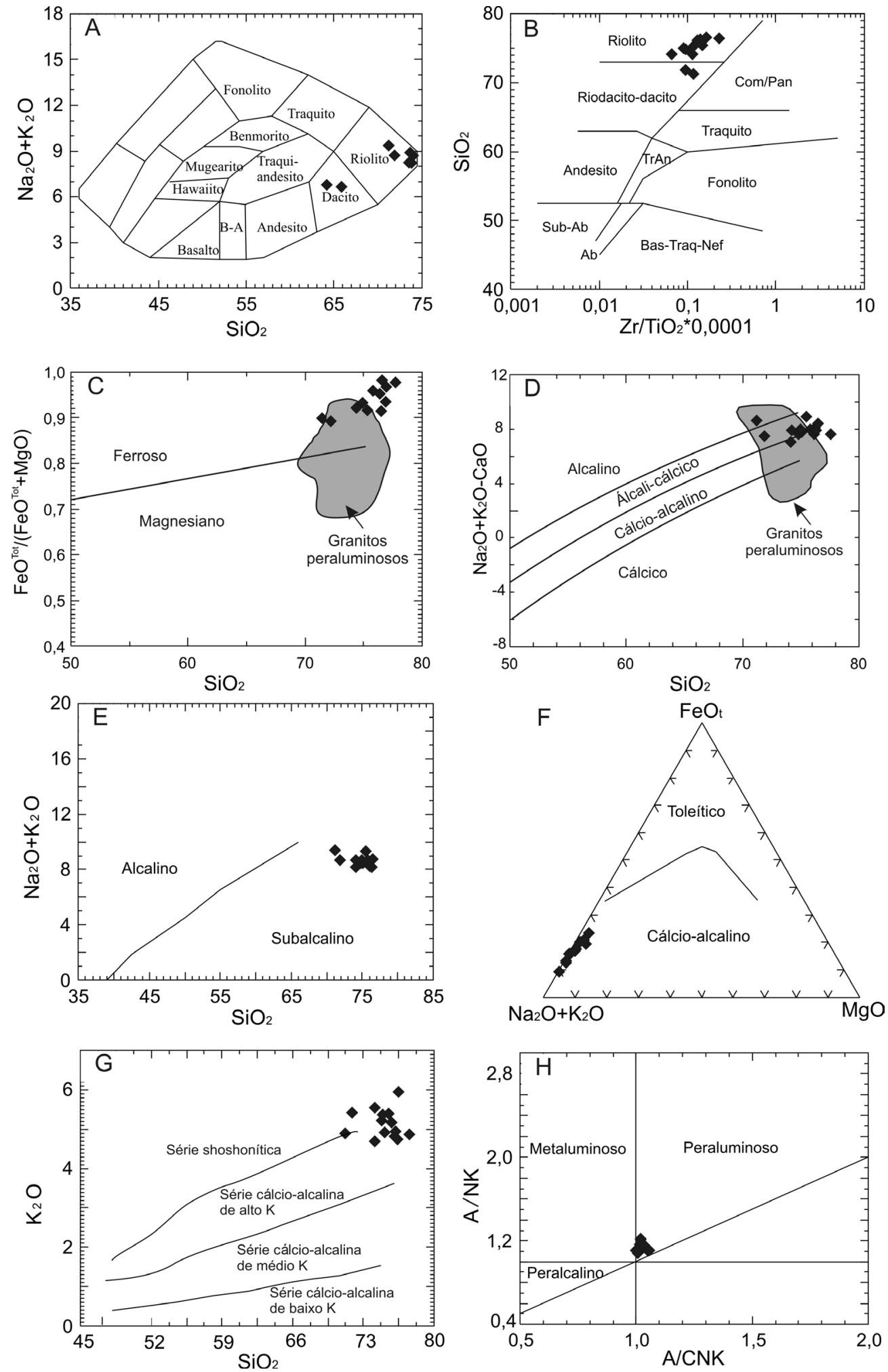

Figura 10. Diagramas geoquímicos para o Granito Encantada. A: Diagrama $\mathrm{Na}_{2} \mathrm{O}+\mathrm{K}_{2} \mathrm{O}$ versus sílica de Cox et al. (1979); B: Diagrama $\mathrm{Zr} / \mathrm{TiO}_{2}{ }^{*} 0,0001$ versus sílica de Winchester e Floyd (1977); C: Diagrama FeOtot/FeOtot + MgO versus $\mathrm{SiO}_{2}$ de Frost et al. (2001); D: Diagrama $\mathrm{Na}_{2} \mathrm{O}+\mathrm{K}_{2} \mathrm{O}-\mathrm{CaO}$ versus $\mathrm{SiO}_{2}$ de Frost et al. (2001); E: Total de álcalis versus sílica e F: AFM (Irvine e Baragar, 1971); G: $\mathrm{K}_{2} \mathrm{O}$ versus $\mathrm{SiO}_{2}$ segundo Peccerillo e Taylor (1976); H: A/NK versus A/CNK segundo Maniar e Piccoli (1989). 

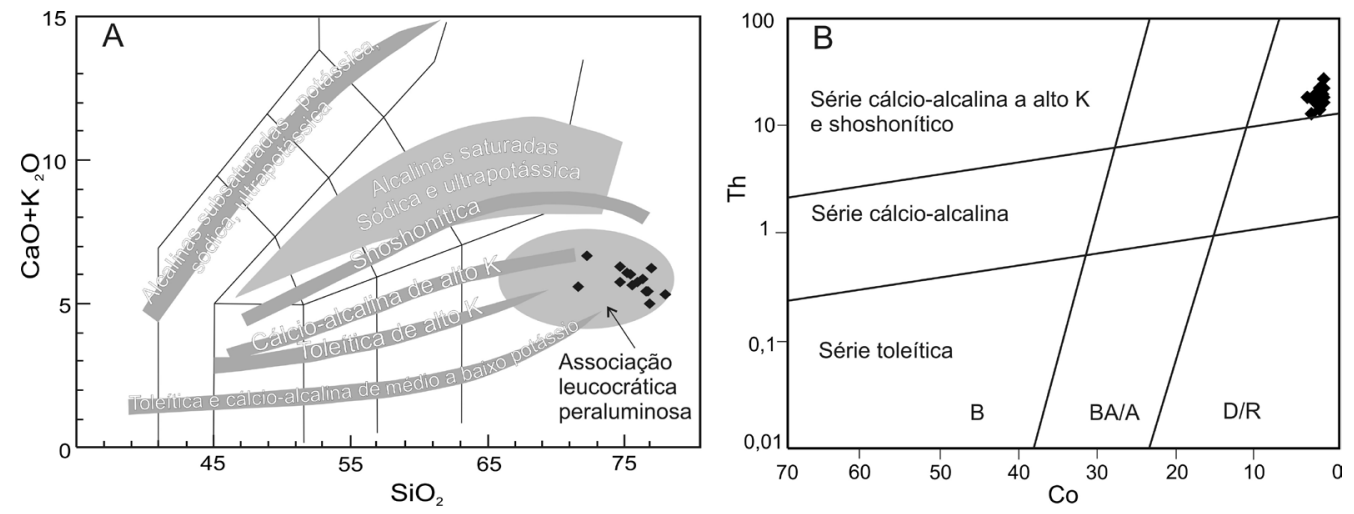

Figura 11. Diagramas geoquímicos para o Granito Encantada. A: Diagrama $\mathrm{CaO}+\mathrm{K}_{2} \mathrm{O}$ versus sílica, com as principais séries magmáticas e produtos de fusão crustal lançados no diagrama TAS (Le Maitre, 2002); B: Diagrama Th versus Co de Hastie et al. (2007).
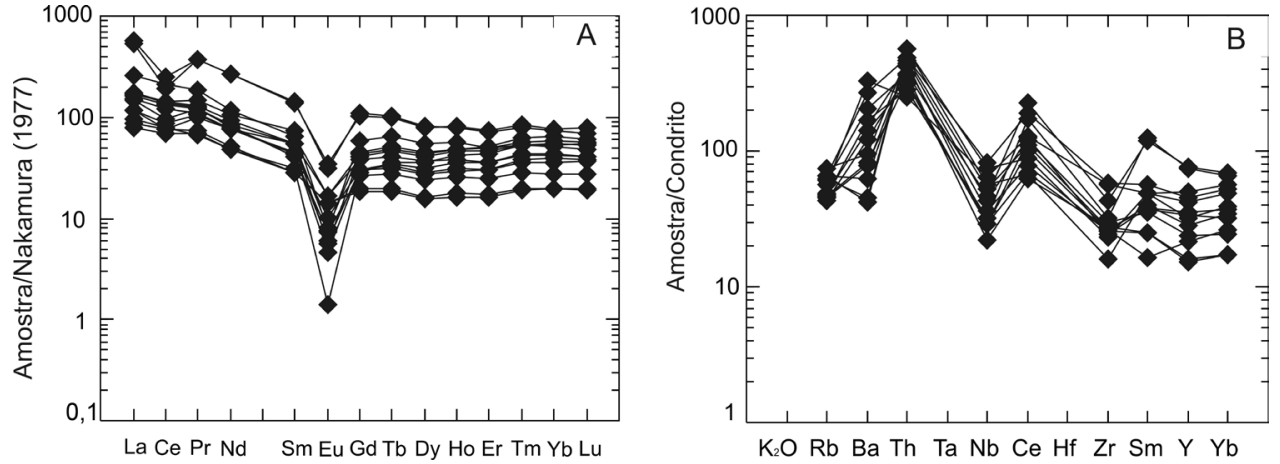

Figura 12. Padrões de distribuição do Granito Encantada nos diagramas. A: ETR, normalizados pelos valores condríticos de Nakamura (1977); B: Elementos traços, normalizados pelos valores da crosta continental segundo Taylor e McLennan (1995).
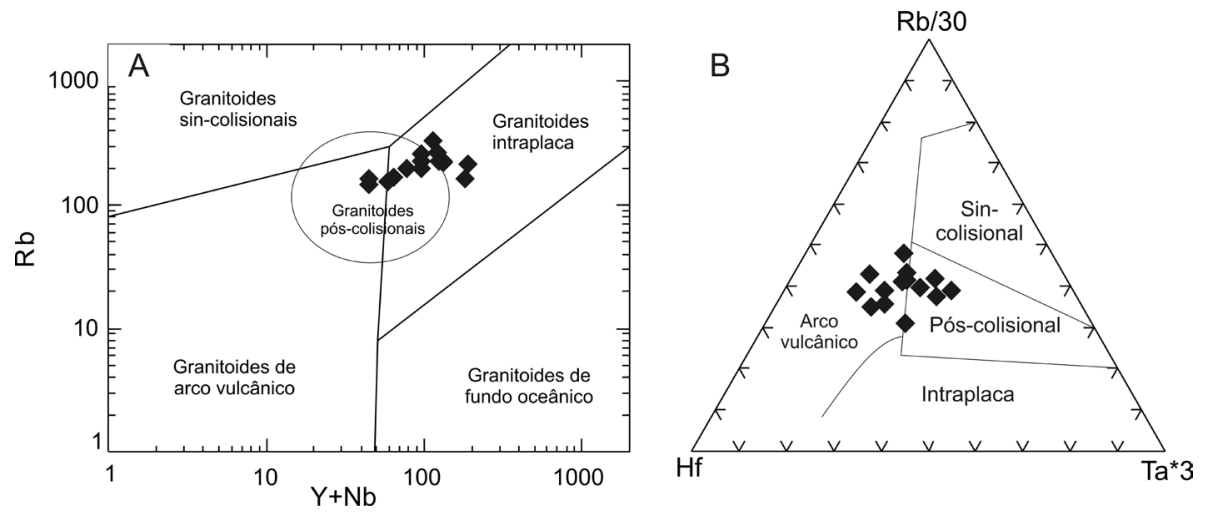

Figura 13. Diagramas de classificação tectônica para o Granito Encantada. A: Rb versus Y+Nb (Pearce et al., 1984; Pearce, 1996); B: Hf-Rb/30-Ta*3 (Harris et al., 1986).

metassedimentares e metavulcânicas no que é denominado Terreno Rio Alegre. Consiste de leucogranitos de composição monzo a sienogranitica, marcados por uma foliação proeminente. Apresenta textura equigranular a inequigranular porfirítica. É composto por quartzo, K-feldspato, plagioclásio, muscovita e biotita, com granada, zircão, alanita, e minerais opacos. Clorita e epidoto são os minerais secundários mais comuns.

$\mathrm{O}$ estudo geoquímico permite classificar o magmatismo que originou os litotipos do Granito Encantada como de caráter ácido, subalcalino, do tipo cálcio-alcalino de alto potássio a 
Tabela 2. Resultados dos cálculos de temperatura das amostras do Granito Encantada. Termometria de saturação em zircão seguido metodologia proposta por Hanchar e Watson (2003). B (exponential), C (Power law), e D (Linear Regression), temperatura de fusão de protólitos pelíticos calculadas pelo termômetro $\mathrm{Al}_{2} \mathrm{O}_{3} / \mathrm{TiO}_{2}$ de Jung e Pfänder (2007).

\begin{tabular}{lccccccccccccc}
\hline $\mathbf{T}\left({ }^{\circ} \mathbf{C}\right)$ & $\mathbf{0 1}$ & $\mathbf{0 2}$ & $\mathbf{0 3}$ & $\mathbf{0 4}$ & 05A & 05B & 06B & 07 & 11A & 11B & 12A & 12B & 13 \\
\hline A & 786,2 & 769,8 & 781,7 & 775,2 & 771,3 & 796,3 & 788,7 & 797,6 & 823,1 & 739,1 & 843,4 & 784,9 & 846,3 \\
B & 811,5 & 815,5 & 843,0 & 815,8 & 812,4 & 889,6 & 884,6 & 767,8 & 900,6 & 740,9 & 948,3 & 803,0 & 922,6 \\
C & 813,0 & 816,7 & 842,1 & 817,0 & 813,8 & 887,0 & 882,0 & 774,4 & 897,9 & 751,5 & 946,9 & 805,3 & 920,5 \\
D & 799,3 & 805,7 & 846,2 & 806,2 & 800,7 & 903,5 & 898,0 & 723,7 & 915,1 & 671,6 & 956,9 & 785,5 & 936,1 \\
\hline
\end{tabular}

shoshonítico. São rochas com índice de saturação de alumina maior que 1 , com coríndon normativo, sendo por isso classificado, geoquimicamente, como um granito relacionado a uma associação leucocrática peraluminosa. Como reflexo do excesso de alumínio, apresenta diversas fases aluminosas, destacando-se muscovita e biotita, além de granada. Apresentam padrão típico de rochas cálcio alcalinas ricas em potássio com enriquecimento de ETR leves sobre pesados.

A idade do Granito Encantada não foi determinada; no entanto, as relações de corte com o Granito Ellus e o Complexo Metavulcano-Sedimentar Rio Alegre permitem realizar uma estimativa da idade de intrusão. A idade mínima é 1470 Ma., idade de cristalização do Granito Ellus que possui xenólitos do Granito Encantada. A idade máxima é de 1509 Ma., que corresponde à idade de cristalização das rochas vulcânicas do Complexo Metavulcano-sedimentar Rio Alegre, cujos litotipos ocorrem como xenólitos no Granito Encantada.

São vislumbradas três origens para o magmatismo granítico peraluminoso: (i) fusão de rochas crustais em zonas profundas de cinturões orogênicos colisionais (por exemplo, Patiño-Douce e McCarty, 1998; Barbarin, 1996; Philipp e Campos, 2010); (ii) pela fusão de rochas metaluminosas félsicas ricas em biotita (Miller, 1985); (iii) fracionamento de magmas básicos ou intermediários (Ellis e Thompson,

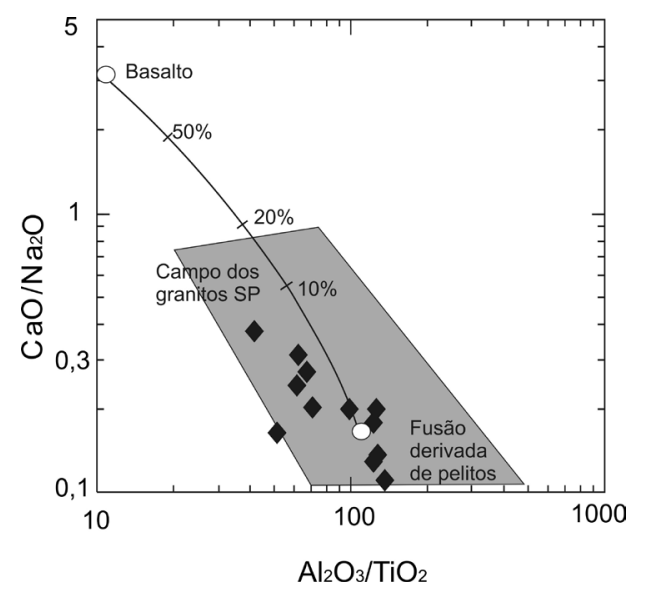

Figura 14. Diagrama $\mathrm{CaO} / \mathrm{Na}_{2} \mathrm{O}$ versus $\mathrm{Al}_{2} \mathrm{O}_{3} / \mathrm{TiO}_{2}$ para avaliação da fonte de magmas peraluminosos segundo Sylvester (1998).
1986; Wilson, 1989). Os dados de campo petrográficos e geoquímicos do Granito Encantada são condizentes com uma evolução associada a magmas gerados a partir da fusão parcial de rochas crustais de composição pelítica. Padrões são similares àqueles descritos para granitos peraluminosos por Barbarin (1996), Sylvester (1998) e Jung e Pfänder (2007). As informações apresentadas sugerem ainda que o Granito Encantada foi gerado a partir da fusão de sedimentos pelíticos em um período pós-colisional, provocado por calor oriundo do manto que aqueceu a base da crosta; sendo causado por ascensão astenosférica seguida de um processo de slab break-off e delaminação litosférica. Este processo é comum nas colisões de alta temperatura (Sylvester, 1998), tais como as Hercinides e Lachlan.

Em etapa posterior, as rochas do Granito Encantada foram afetadas por esforços compressivos, o que gerou a foliação associada ao transporte tectônico de WSW para ENE. Esse evento relacionado à orogenia San Ignácio foi datado através do método Ar-Ar por De Paulo (2004), que obteve idades entre $1378 \pm 4$ Ma. e $1322 \pm 2$ Ma. dos anfibólios, de metabasaltos da Sequência Metavulcano-Sedimentar Rio Alegre.

\section{AGRADECIMENTOS}

Os autores agradecem à CAPES pelo suporte financeiro para o desenvolvimento da pesquisa. Ao Serviço Geológico do Brasil (CPRM) pela cessão dos dados do PRONAGEO. A primeira autora agradece à CAPES pela concessão de bolsa de mestrado, bem como ao orientador e a coorientadora, pela paciência e dedicação, e aos seus amigos que colaboraram para realização deste trabalho.

\section{REFERÊNCIAS}

Barbarin, B. (1996). Genesis of the two main types of peraluminous granitoids. Geology, 24 (4), 295-298.

Barbarin, B. (1999). A review of the relationships between granitoid types, their origins and their geodynamic environments. Lithos, 46(2), 605-626. 
Bettencourt, J. S., Leite Jr, W. B., Ruiz, A. S., Matos, R., Payolla, B. L., Tosdal, R. M. (2010). The Rondonian-San Ignácio Province in the SW Amazonian Craton: an overview. Journal of South American Earth Sciences, 29(1), 28-46.

Campos, M. S. (2008). Caracterização Geológica e Estrutural do Granito Ellus - Domínio Tectônico Rio Alegre - SW do Estado de Mato Grosso. Trabalho de Conclusão de Curso (Graduação em Geologia). Cuiabá: Instituto de Ciências Exatas e da Terra - UFMT.

Chappell, B. W., White, A. J. R. (1992). I- and S-type granites in the Lachlan Fold Belt. Royal Society of Edinburgh Transactions Earth Sciences, 83(1-2), 1-26.

Cordani, U. G., Teixeira, W. (2007). Proterozoic accretionary belts of the Amazonian Craton. In: R. D. Hatcher Jr., M. P. Carlson, J. H. Mcbride, J. R. Martinez Catalán (Eds.), The 4D Framework of Continental Crust (297-320). Boulder: Geological Society of America.

Cox, K. G., Bell, J. D., Pankhurst, R. J. (1979). The Interpretation of Igneous Rocks. Londres: George Allen \& Unwin.

Deer, W. A., Howie, R. A., Zussman, J., Wise, W. S. (2004). Rock Forming Minerals: Framework silicates. Silica minerals, Feldspathoids and the Zeolites (2a. ed., vol. 4B). Londres: Geological Society of London.

De Paulo, V. G. (2004). Identificação dos Eventos Termotectônicos através do Método 40Ar/39Ar, nos Terrenos Jauru, Pontes e Lacerda e Rio Alegre - SW do Cráton Amazônico. Dissertação (Mestrado). Rio de Janeiro: Faculdade de Geologia - UERJ.

Ellis, D. J., Thompson, A.B. (1986) Subsolidus and partial melting reactions in the quartz-excess $\mathrm{CaO}+\mathrm{MgO}+\mathrm{Al}_{2} \mathrm{O}_{3}+\mathrm{SiO}_{2}+\mathrm{H} 2 \mathrm{O}$ system under water-excess and water deficient conditions to $10 \mathrm{~kb}$ : Some implications for the origin of peraluminous melts from mafic rocks. Journal of Petrology, 27(1), 91-121.

Frost, B. R., Barnes, C. G., Collins, W. J., Arculus, R. J., Ellis, D. J., Frost, C. D. (2001). A geochemical classification for granitic rocks. Journal of Petrology, 42(11), 2033-2048.

Geraldes, M. C. (2000). Geocronologia e geoquímica do plutonismo mesoproterozoico do SW do Estado do Mato Grosso (SW do Cráton Amazônico). Tese (Doutorado). São Paulo: Instituto de Geociências - USP.

Geraldes, M. C., Van Schmus, W. R., Condie, K. C., Bell, S., Teixeira, W., Babinski, M. (2001). Proterozoic geologic evolution of the SW part of the Amazonian Craton in Mato Grosso state, Brazil. Precambrian Research, 111 (1-4), 91-128.

Hanchar, M., Watson, E. B. (2003). Zircon Saturation Thermometry. In: J. M. Hanchar, P. W. O. Hoskin (Eds.), Zircon: Reviews in Mineralogy and Geochemistry (v. 53, 89-112). Washington: Mineralogical Society of America.

Harris, N. B. W., Pearce, J. A., Tindal, A. G. (1986). Geochemical characteristics of collision-zone magmatism. In: M. P. Coward, A. C. Ries (Eds.), Collision Tectonics (v. 19, 67-81). London: The Geological Society.

Hastie, A. R., Kerr, A. C., Pearce, J. A., Mitchell, S. F. (2007). Classification of altered volcanic island arc rocks using immobile trace elements: development of the Th Co discrimination diagram. Journal of Petrology, 48(12), 2341-2357.

Imeokpar, E. G. (1981). Ba/Rb and $\mathrm{Rb} / \mathrm{Sr}$ ratios as indicators of magmatic fractionation, post magmatic alteration and mineralization - Afu Younger Granite Complex Northern Nigeria. Geochemical Journal, 15(4), 209-219.

Irvine, T. N., Baragar, W. R. A. (1971). A guide to the chemical classification of the common volcanic rocks. Canadian Journal of Earth Sciences, 8(5), 523-548.

Janasi, V. A., Alves, A., Vlach, S. R. F., Leite, R. J. (2003). Granitos peraluminosos da porção central da Faixa Ribeira, Estado de São Paulo: sucessivos eventos de reciclagem da crosta continental no neoproterozoico. Geologia USP-Série Cientifica, 3(1), p. 13-24.

Jung, S., Pfänder, J. A. (2007). Source composition and melting temperatures of orogenic granitoids: constrains from $\mathrm{CaO} / \mathrm{Na}_{2} \mathrm{O}, \mathrm{Al}_{2} \mathrm{O}_{3} / \mathrm{TiO}_{2}$ and accessory mineral saturation thermometry. European Journal of Mineralogy, 19(6), 859-870.

Le Fort, P., Cuney, M., Deniel, C., France-Lanord, C., Sheppard, S. M. F., Upreti, B. N., Vidal, P. (1987). Crustal generation of the Himalayan leucogranites. Tectonophysics, 134(1-3), 39-57.

Le Maitre, R. W. (1989). A classification of igneous rocks and glossary of terms: recommendations of the international union of geological sciences subcommission on the systematics of igneous rocks. Oxford: Blackwell.

Le Maitre, R. W. (2002). Igneous rocks - a classification and glossary of terms. Recommendationsof the IUGS subcommission. Cambridge: Cambridge University Press. 
Maniar, P. D., Piccoli, P. M. (1989). Tectonic discrimination of granitoids. Geological Society of America Bulletin, 101(5), 635-643.

Matos, J. B. (1995). Contribuição à geologia de parte da porção meridional do Cráton Amazônico: região de Rio Alegre (MT). Dissertação (Mestrado). São Paulo: Instituto de Geociências - USP.

Matos, J. B., Schorscher, J. H. D., Geraldes, M. C., Sousa, M. Z. A., Ruiz, A. S. (2004). Petrografia, Geoquímica e geocronologia das rochas do orógeno Rio Alegre, Mato Grosso: um registro de crosta oceânica mesoproterozóica no SW do Cráton Amazônico. Geologia USP - Série Científica, 4(1), 75-90.

Miller, C. F. (1985). Are strongly peraluminous magmas derived from pelitic sedimentary sources? Journal of Geology, 93(6), 673-689.

Miller, C. F., Stoddard, E. F., Bradfish, L. J., Dollase, W. A. (1981). Composition of plutonic muscovite: genetic implications. Canadian Mineralogist, 19(1), 25-34.

Nakamura, K. (1977). Volcanoes as a possible indicator of tectonic stress orientation: principle and proposal. Journal of Volcanology and Geothermal Research, 2, 1-16.

Patiño Douce, A. E., Johnston, A. D. (1991). Phase equilibria and melt productivity in the pelitic system: implications for the origin of peraluminous granitoids and aluminous granulites. Contributions to Mineralogy and Petrology, 107(2), 202-218.

Patiño Douce A. E. (1999). What do experiments tell us about the relative contributions of crust and mantle to the origin of granitic magmas? In: A. Castro, C. Fernandez, J. E. Vigneresse (Eds.), Undestanding granites: New and Classical Techniques (v. 168, 55-75). Londres: Geological Society of London.

Patiño-Douce, A. E., McCarthy, T. C. (1998). Melting of crustal rocks during continental collision and subduction. In: B. R. Hacker, J. G. Liou (Eds.), When the continents collide: geodynamics and geochemistry of Ultra-High Pressure rocks (v. 1, 27-55). Países Baixos: Kluwer Academic Publishers.

Pearce, J. A. (1996). Sources and settings of granitic rocks. Episodes, 19(4), 120-125,

Pearce, J. A., Harris, N. B. W., Tindle, A. G. (1984). Trace element discrimination diagrams for the tectonic interpretation of granitic rocks. Journal of Petrolog, 25(4), 956-983.
Peccerillo, A., Taylor, S. R. (1976). Geochemistry of Eocene calc-alkaline volcanic rocks from the Kastamonu area, Northern Turkey. Contributions to Mineralogy and Petrology, 58(1), 63-81.

Philipp, R. P., Campos, R. S. (2010). Granitos peraluminosos intrusivos no Complexo Metamórfico Brusque: registro do magmatismo relacionado a colisão neoproterozoica no Terreno Tijucas, Itapema (SC). Revista Brasileira de Geociências, 40(3), 303-320.

Ruiz, A. S. (2005). Evolução geológica do sudoeste do Cráton Amazônico: região limítrofe Brasil-Bolivia-Mato Grosso. Tese (Doutorado). Rio Claro: Instituto de Geociências e Ciências Exatas - UNESP.

Seer, H. J., Brod, J. A., Valeriano, C. M., Fuck, R. A. (2005). Leucogranitos intrusivos no grupo Araxá: registro de um evento magmático durante colisão neoproterozoica na porção meridional da faixa Brasília. Revista Brasileira de Geociências, 35(1), 33-42.

Silva, C. H., Costa, A. C. D., Matos, J. B., Ruiz, A. S., Costa, P. C. C., Sousa, M. Z. A., Batata, M. E. F., Lima, G. A. (2012). Geologia da Folha SE-21-V-A-II - Santa Rita. Programa Nacional de Geologia. Serviço Geológico do Brasil. Cuiabá: Universidade Federal de Mato Grosso.

Streckeisen, A. L. (1976). To each plutonic rock its proper name. Earth-Science Reviews, 12(1), 1-13.

Sun, S. S., McDonough, W. F. (1989). Chemical and isotopic systematics of oceanic basalts: implications for mantle composition and processes. In: A. D. Saunders, M. J. Norry (Eds.), Magmatism in ocean basins (v. 42, 313-345). Londres: Geological Society.

Sylvester, P. J. (1998). Post-collisional strongly peraluminous granites. Lithos, 45(1-4), 29-44.

Tassinari, C. C. G., Macambira, M. J. B. (1999). Geochronological provinces of the Amazonian Craton. Episodes, 22(3), 174-182.

Taylor, S. R., McLennan, S. M. (1995). The geochemical evolution of the continental crust. Reviews in Geophysics, 33(2), 241-265.

Wilson, M. (1989). Igneous Petrology. Londres: Unwin Hyman.

Winchester, J. A., Floyd, P. A. (1977). Geochemical discrimination of different magma series and their differentiation products using immobile elements. Chemical Geology, 20, 325-343. 